\title{
Natural history and conservation of the endemic avifauna in north-west Peru
}

\author{
THEODORE A. PARKER, III, THOMAS S. SCHULENBERG, \\ MICHAEL KESSLER and WALTER H. WUST
}

\section{Summary}

Roughly $30 \%$ of the avifauna of the dry tropical forests of north-western Peru and adjacent south-western Ecuador is endemic to this small region. Large areas in this region, especially on the Ecuadorian side of the border, have been deforested, further heightening the threatened conservation status of this fauna. The largest remaining tracts of forest in this region are in the Bosque Nacional de Tumbes, Peru. This forest, which was visited in 1986 and 1988, holds significant populations of 12 threatened or near-threatened species, and smaller populations of at least three more endangered species. Six species (Aramides axillaris, Thalurania colombica, Picumnus olivaceus, Attila torridus, Arremonops conirostris, Carduelis siemiradzkii) are reported in Peru for the first time. Evidence is presented for seasonal movements of some species, including the threatened Leptotila ochraceiventris and in the small Peruvian population of Pionus chalcopterus. Based primarily on vocal evidence, it is proposed that Thamnophilus zarumae and Grallaria watkinsi be recognized as full species, and that "Empidonax" griseipectus be transferred to Lathrotriccus; further work is needed on the species status of endemic forms in other polytypic species such as Sittasomus griseicapillus and Pyriglena leuconota.

Aproximadamente $30 \%$ de la avifauna de los bosques secos tropicales del noroeste del Perú, y del suroeste de Ecuador, es endémica a esta pequeña región. Extensas areas en esta región, especialmente del lado de la frontera ecuatoriana, han sido deforestadas, aumentando así la amenaza para la conservación de la fauna. Los más grandes vestigios de bosque seco tropical que subsisten en esta región están localizados en el Bosque Nacional de Tumbes en el Perú. Este bosque, que fue visitado en 1986 y 1988, tiene poblaciones significativas de 12 especies amenazadas o con posible amenaza de extinción, y poblaciones pequeñas de 3 especies más que están en peligro de desaparecer. Notas sobre la historia natural son presentadas para 28 especies, incluyendo 11 especies que están amenazadas o en peligro de extinción. Seis especies (Aramides axillaris, Thalurania colombica, Picumnus olivaceus, Attila torridus, Arremonops conirostris, Carduelis siemiradzkii) están reportados en el Perú por primera vez. Evidencia es presentada para movimientos estacionales de algunas especies, incluyendo la amenazada Leptotila ochraceiventris y la población pequeña peruana de Pionus chalcopterus. Basandose principalmente en evidencia vocal, se propone que Thamnophilus zarumae y Grallaria watkinsi pueden ser reconocidas como especies y que "Empidonax" griseipectus puede ser transferido a Lathrotriccus. Se necesita más estudios para determinar el estatus de las formas endémicas de especies politípicas como Sittasomus griseicapillus y Pyriglena leuconota.

\section{Preface}

The first draft of this manuscript was prepared by the late Ted Parker in the fall of 1988. A revised version was widely circulated via the International Council for 
Bird Preservation, as a result of which its direct and indirect influences can be seen in most of the recent publications that deal with this endemic avifauna (Best and Clarke 1991, Best 1992, Collar et al. 1992, Best et al. 1993a, 1993b). This renewed interest in - and greater appreciation for the threatened status of this avifauna only increases the importance of publishing Parker's manuscript, and of making it available to a wider audience. We have tried to publish a version that is as close as possible to the last draft that Ted had approved for publication. We encourage readers interested in this avifauna also to consult the sources listed above; T.S.S. has added parenthetical references to these sources in a few species accounts, as well as to Parker and Carr (1992).

\section{Introduction}

The purpose of this paper is to draw attention to the extraordinarily high degree of bird endemism in dry tropical forests of north-western Peru and adjacent Ecuador; thereby to emphasize their importance to conservationists; and to present natural history notes on some of these species. The significance of this region as a centre of endemism has long been recognized (Chapman 1926, Müller 1973, Cracraft 1985). These authors have delineated somewhat different boundaries for the area of interest, but the region of highest endemism extends from the Río Chone, north of Guayaquil, Ecuador, south to the latitude of Chiclayo, Peru. We follow Cracraft (1985) in referring to this as the "Tumbesan Center". The Tumbesan Centre is bordered to the north by the "Colombian-Pacific" faunal area of Chapman (1917, 1926), or the "Chocó Rainforest Center" of Cracraft (1985), a region characterized by its very humid rainforest vegetation and extremely high plant species diversity (Gentry 1982); to the east by the Andes mountains; to the south by the arid coastal plain of central Peru; and to the west by the Pacific Ocean. The dry forests of the upper Río Marañón, and its associated fauna, have many affinities to those of the Pacific slope, and we regard the avifauna of these forests as a subset of the Tumbesan Centre.

Dry forests in this small area should be of particular interest to conservationists. Formerly, a nearly unbroken expanse of this habitat extended from the Cordillera de Chongón in Ecuador south to the west slope of the Andes east of Chiclayo, Peru. Within the past 30 years this habitat has been reduced to scattered, small fragments of heavily exploited forest surrounded by croplands and pasture (Dodson and Gentry 1991). One of the last large $\left(>_{15}, 000 \mathrm{ha}\right)$, nearly pristine tracts of semi-deciduous mixed with evergreen forest occurs within the Bosque Nacional de Tumbes, Peru, situated between the Ecuadorian border and the Río Tumbes to the west. When combined with the contiguous Parque Nacional Cerros de Amotope and the Coto de Caza El Angolo to the south-west (Figure 1), the entire network of reserves encompasses 231,402 ha of forest and scrub (Dourojeanni and Ponce 1978). Unfortunately, however, nearly all of the forest west of the Río Tumbes (i.e. the forest in the national park and coto) is lower, more deciduous, and considerably drier than that which lies within c. $20 \mathrm{~km}$ of the Ecuadorian border (the late A. H. Gentry verbally to T.A.P.). We doubt that many of the most critically threatened bird species of this habitat, or primate species such as Alouatta palliata and Cebus 

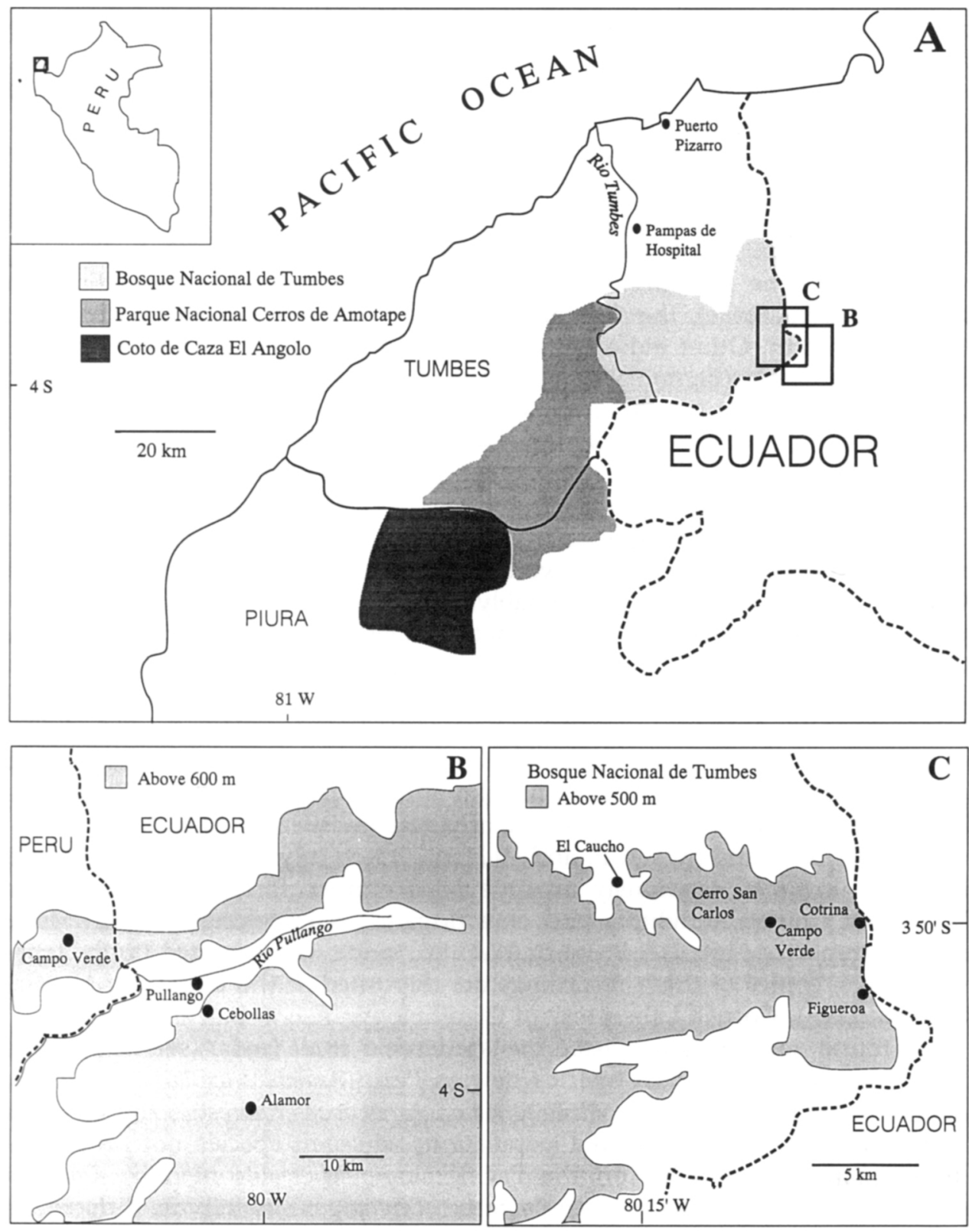

Figure 1. (a) The department of Tumbes and the northern part of the department of Piura, showing protected areas in this region. Inset map shows this area in relation to the rest of Peru. (b) South-eastern portion of the Bosque Nacional de Tumbes and American Museum of Natural History (AMNH) collecting sites in adjacent Ecuador (see Table 1). The exact locations of AMNH sites Guianche, Las Piñas and El Puente are not known (Paynter 1993). All of these sites are clearly near Alamor, however (Chapman 1926: 1415). (c) South-eastern Bosque Nacional de Tumbes, showing sites mentioned in the text. 
albifrons (Dourojeanni and Ponce 1978), occur in Tumbes south of the Bosque Nacional. We estimate that less than 15,000 ha of species-rich semi-deciduous and evergreen forest survives within the Bosque Nacional de Tumbes, and similar habitat in immediately adjacent Ecuador has disappeared almost entirely (Dodson and Gentry 1991, pers. obs.).

Tosi (1960) also noted the more humid character of the forest in the Bosque Nacional de Tumbes. Dominant trees include the impressive, grey-barked Cavanillesia platanifolia (Bombacaceae), the most conspicuous tree between c.400 and $900 \mathrm{~m}$ in the semi-deciduous forest, and smooth green-barked Eriotheca discolor (Bombacaceae), the dominant large tree in lower, drier forest between c. 200 and $500 \mathrm{~m}$. Other indicator species of the semi-deciduous forest include Tabebuia chrysantha (Bignoniaceae); Cordia sp. (Boraginaceae); Bursera graveolens (Burseraceae); Clusia spp. (Guttiferae); Centrolobium ochroxylum, Erythrina sp., Pithecellobium multiflorum (Leguminosae); Cedrela sp. (Meliaceae); Brosimum sp., Castilla elastica, Cecropia sp., Ficus sp. (Moraceae); Triplaris guayaquilensis (Polygonaceae); and Guazuma ulmifolia (Sterculiaceae). The epiphytic bromeliad Tillandsia usneoides is abundant on tree limbs and branches (plant data from Tosi 1960 and the late A. H. Gentry verbally to T.A.P.). The evergreen forest at Campo Verde and Cotrina presumably contains a much greater diversity of plants, including many endemic and potentially threatened taxa (the late $\mathrm{A}$. $\mathrm{H}$. Gentry verbally to T.A.P.). A botanical survey of the area is urgently needed.

The avifauna of the Bosque Nacional de Tumbes was first studied in JuneJuly 1979 by Wiedenfeld et al. (1985), who recorded 149 species in the El CauchoCampo Verde area. Specimens were obtained for 109 species, and are deposited at the Louisiana State University Museum of Natural Science (LSUMZ) and the Museo de Historia Natural, Lima. The area was revisited by M.K. (25 February to 3 March 1986) and by T.A.P. and W.H.W. (23-27 July 1988). The latter three observers explored previously unsurveyed evergreen forest between Campo Verde and Cotrina, a military post on a ridge-top overlooking Ecuador. Many species reported by T.A.P. and W.H.W. were documented with taperecordings; copies of these recordings are deposited at the Library of Natural Sounds (LNS), Cornell Laboratory of Ornithology.

We found 32 species not listed by Wiedenfeld et al. (1985) (see Appendix), including the following six species new to Peru: Aramides axillaris, Thalurania colombica, Picumnus olivaceus, Attila torridus, Arremonops conirostris and Carduelis siemiradzkii. We also discovered populations of seven species not previously known south of Ecuador on the Pacific slope: Micrastur ruficollis, Columba speciosa, Columba subvinacea, Xenops minutus, Leptopogon superciliaris, Platyrinchus mystaceus and Tachyphonus luctuosus. The little-known Leptotila ochraceiventris, Lathrotriccus griseipectus, and Conothraupis speculigera were found for the first time in the department of Tumbes, as were Grallaria guatimalensis, Catharus ustulatus and Pipraeidea melanonota. Several widespread species such as Casmerodius albus, Egretta thula, Buteo magnirostris and Micrastur semitorquatus were added to the Bosque Nacional de Tumbes list. M.K. discovered that numerous species (e.g. Leptotila ochraceiventris, Nyctidromus albicollis, Turdus maculirostris, Vireo olivaceus [singing; presumably the resident subspecies griseobarbata], Geothlypis aequinoctialis, and Basileuterus fraseri) were considerably more common (or vocal) during the wet season (December-April), whereas others, notably the orioles Icterus mesomelas and I. graceannae, were not found 
Table 1. Species recorded from localities near Peru

\begin{tabular}{ll}
\hline & \multicolumn{1}{c}{ Adjacent Ecuadorian sites } \\
\hline Odontophorus erythrops & Alamor \\
Amazilia tzacatl & Alamor, Guainche, Cebollal, Las Piñas \\
Aglaiocercus coelestis & Alamor \\
Heliothry $x$ barroti & Río Pullango, La Puente \\
Aulacorhynchus haematopygius & Alamor, Las Piñas \\
Thamnophilus atrinticha & Las Piñas \\
Mymeciza immaculata & Las Piñas \\
Anabacerthia iariegaticeps & Alamor \\
Thryothorus mystacalis & Alamor, Las Piñas \\
Tangara icterocephala & Alamor, Las Piñas \\
Ramphocelus icteronotus & Alamor, Río Pullango, Cebollal, Las Piñas \\
\hline
\end{tabular}

${ }^{a}$ Chapman (1926).

'Recognized as a species separate from Thamnophilus punctatus, following Isler et al. (unpub.).

Recognized as a species separate from Thryothorus genibarbis, following Ridgely and Tudor (1989).

at all. The latter two species and other nectarivores may occur in the area mainly during the dry season when the trees Cavanillesia platanifolia and Erythrina sp. are flowering. More intensive fieldwork, especially during the rainy season, would further elucidate seasonal changes, and would probably yield further additions to the avifauna of Peru, especially during the extremely wet El Niño years. At least 11 additional species not yet known from Peru have been recorded in Ecuador within 20 to $30 \mathrm{~km}$ of the Peruvian border (Table 1 ).

Fully $25 \%$ of the species now known from the Bosque Nacional de Tumbes are restricted to the Tumbesan Centre; even more impressively, two-thirds of the bird taxa endemic to this faunal region occur within the Bosque Nacional (Table 2). Fourteen species are known in Peru only from the Bosque Nacional (Table 3), and what may be the largest remaining populations of several species regarded as threatened or endangered (Collar et al. 1992, Parker et al. in press) occur within the reserve. For these reasons, we strongly recommend that steps be taken fully to protect the flora and fauna of this critical area.

During the visit in July 1988, the road to El Caucho was being re-opened. The heavy rains and floods of 1983, an El Niño year, had left this area isolated until then. T.A.P. and W.H.W. saw signs of logging and hunting along the new road. Soldiers at the military posts along the Ecuadorian border regularly hunt chachalacas, guans and large mammals to supplement their meagre food rations. If properly educated and provisioned with adequate food the soldiers would certainly be able to help ensure the survival of this unique forest.

Accounts are presented for 28 species, including 11 that are regarded as endangered or threatened (Collar et al. 1992, Parker et al. in press), those that represent important distributional records (new records for Peru or for the Pacific Coast region of Peru), and those for which there is important new information on natural history that may bear on species-level taxonomy.

\section{Species accounts}

\section{Pale-browed Tinamou Crypturellus transfasciatus}

This species was common at El Caucho, where up to 12 individuals were seen or heard daily within $1 \mathrm{~km}$ of the military post. Fewer were noted on Cerro San 
Table 2. Bird species endemic to the Tumbesan Centre of Endemism

\begin{tabular}{|c|c|c|c|}
\hline \multirow[b]{2}{*}{ Crypturellus transfasciatus* } & \multicolumn{2}{|c|}{ Threat $^{\mathrm{a}}$} & \multirow{2}{*}{$\frac{\text { Forest-dependent }}{x}$} \\
\hline & NT & $\mathrm{T}$ & \\
\hline Leucopternis occidentalis ${ }^{*}$ & E & $\mathrm{T}$ & $x$ \\
\hline Ortalis erythroptera ${ }^{*}$ & NT & $\mathrm{T}$ & $x$ \\
\hline Penelope albipennis(*?) & $\mathrm{E}$ & $\mathrm{E}$ & $x$ \\
\hline Columbina buckleyi* & & & $x$ \\
\hline Leptotila ochraceiventris* & $\mathrm{E}$ & $\mathrm{T}$ & $\mathrm{X}$ \\
\hline Aratinga erythrogenys* & NT & $\mathrm{V}$ & $X ?$ \\
\hline Forpus coelestis ${ }^{*}$ & & & $X ?$ \\
\hline Brotogeris pyrrhopterus* & NT & $\mathrm{V}$ & $x$ \\
\hline Caprimulgus anthonyi & & $\mathrm{V}$ & \\
\hline Phaethornis (griseogularis) porcullae* & & & $x$ \\
\hline \multicolumn{4}{|l|}{ Leucippus baeri } \\
\hline Thalurania (colombica) hypochlora* & & $\mathrm{V}$ & $x$ \\
\hline \multicolumn{4}{|l|}{ Myrmia micrura } \\
\hline Picumnus sclateri* & & & $x$ \\
\hline Veniliornis callonotus* & & & $x$ \\
\hline Campephilus guayaquilensis* & & $\mathrm{V}$ & $x$ \\
\hline Sittasomus (griseicapillus) aequatorialis* & & & $x$ \\
\hline \multicolumn{4}{|l|}{ Furnarius (leucopus) cinnamomeus* } \\
\hline Synallaxis tithys* & $\mathrm{E}$ & V & $x$ \\
\hline Synallaxis stictothorax* & & $\mathrm{V}$ & $x$ \\
\hline Syndactyla ruficollis* & $E$ & V & $x$ \\
\hline Hylocryptus erythrocephalus ${ }^{*}$ & $I$ & $\mathrm{~V}$ & X \\
\hline Sakesphorus bernardi* & & & $X ?$ \\
\hline Thamnophilus zarumae ${ }^{\star}$ & & $\mathrm{T}$ & $x$ \\
\hline Pyriglena (leuconota) pacifica ${ }^{*}$ & & $\mathrm{~V}$ & $x$ \\
\hline Myrmeciza griseiceps* & $E$ & $\mathrm{~T}$ & $x$ \\
\hline Grallaria watkinsi* & & $\mathrm{T}$ & $x$ \\
\hline Melanopareia elegans* & & & $x$ \\
\hline Myiopagis subplacens* & & $\mathrm{V}$ & $x$ \\
\hline \multicolumn{4}{|l|}{ Myiopagis leucospodia } \\
\hline Tolmomyias (sulphurescens) aequatorialis* & & & $x$ \\
\hline Onychorhynchus (coronatus) occidentalis* & $\mathrm{E}$ & $\mathrm{T}$ & $x$ \\
\hline Lathrotriccus griseipectus* & $\mathrm{V} / \mathrm{R}$ & $\mathrm{T}$ & $x$ \\
\hline \multicolumn{4}{|l|}{ Fluvicola (nengeta) atripennis } \\
\hline Tumbezia salvini & & & $x$ \\
\hline Attila torridus* & $\mathrm{E}$ & $\mathrm{T}$ & $\mathrm{X}$ \\
\hline Myiarchus semirufus & & $\mathrm{V}$ & \\
\hline Myiarchus phaeocephalus* & & & $x$ \\
\hline Myiodynastes bairdit & & & $x$ \\
\hline \multicolumn{4}{|l|}{ Tyrannus niveigularis } \\
\hline Pachyramphus spodiurus ${ }^{*}$ & $\mathrm{E}$ & V & $x$ \\
\hline Phytotoma raimondii & $\mathrm{E}$ & $\mathrm{T}$ & \\
\hline
\end{tabular}

Hirundo rufocollaris

Tachycineta (albilinea) stolzmanni

Cyanocorax mystacalis*

Thryothorus superciliaris*

Thryothorus (sclateri) paucimaculatus*

V

Turdus reevei

Turdus maculirostris*

$\mathrm{V}$

$x$

Icterus graceannae*

Basileuterus trifasciatus ${ }^{*}$

Basileuterus fraseri*

Piezorhina cinerea

Sicalis taczanowskii 
Table 2. continued

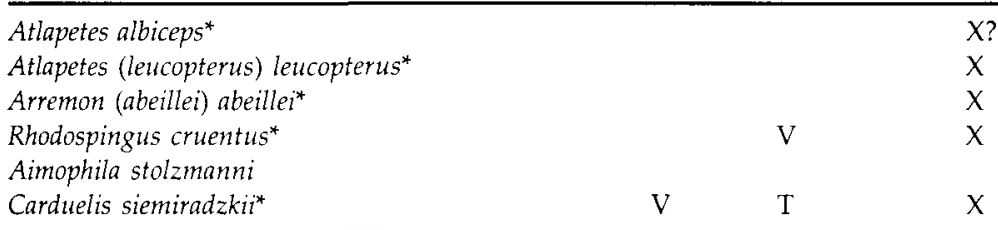

"Two rating schemes for the degree of threat are presented for each species. The first (left-hand column) is based on Collar et al. (1992), and uses the following categories (in decreasing order) of threat: E (Endangered), V (Vulnerable), R (Rare), I (Indeterminate), and NT (Near-Threatened). The second rating (right-hand column) is based on Parker et al. (in press), using the following categories (in decreasing order) of threat: E (Endangered), T (Threatened), and V (Vulnerable).

* Recorded in the Bosque Nacional de Tumbes.

() Taxa that are isolated populations of more widespread species that may be sufficiently distinct morphologically and behaviourally to be regarded as full species.

Table 3. Species restricted in Peru to the Bosque Nacional de Tumbes

Leucopternis occidentalis
Ortalis erythroptera
Damophila julie
Chalybura buffonii
Thalurania colombica
Picumnus olivaceus
Veniliornis kirkii
Synallaxis brachyura
Grallaria watkinsi
Attila torridus
Turdus maculirostris
Hylophilus. minor
Arremonops conirostris
Carduelis siemiradzkii

Carlos, and none was found in the Campo Verde-Cotrina area, where they probably occur in small numbers. At El Caucho this tinamou seemed to prefer shady areas with a continuous cover of small vine-covered, leafy trees within the tall bombacaceous forest. Most were recorded on the lower slopes of narrow valleys and in deep ravines, but several were heard calling from drier, more open forest higher on ridges, so the species is not restricted to the greenest portions of the forest. Tinamous were heard only at dusk, but then in chorus. Up to 10 individuals were heard during brief periods after sunset $x \mathrm{~km}$ north-east of the military post in upper Quebrada Faical. The song is a loud, resonant whoooit, generally given at intervals longer than 30 seconds (Figure 2a). The reverberating notes of several birds calling alternately produced an unusual echo effect within the narrow valley. On 23 July, under partly cloudy skies with no moon visible, the first bird sang at $18 \mathrm{~h} 35$, the last at $18 \mathrm{~h} 45+$. On the moonlit night of 26 July, the first sang at $18 \mathrm{~h}_{40}$, the last at 19 hoo.

The total population of this species within the Bosque Nacional de Tumbes must number in the thousands, because habitat disturbance and hunting pressure on tinamous appears to be almost non-existent at present. Additional information on the distribution and behaviour of $C$. transfasciatus in Peru was 

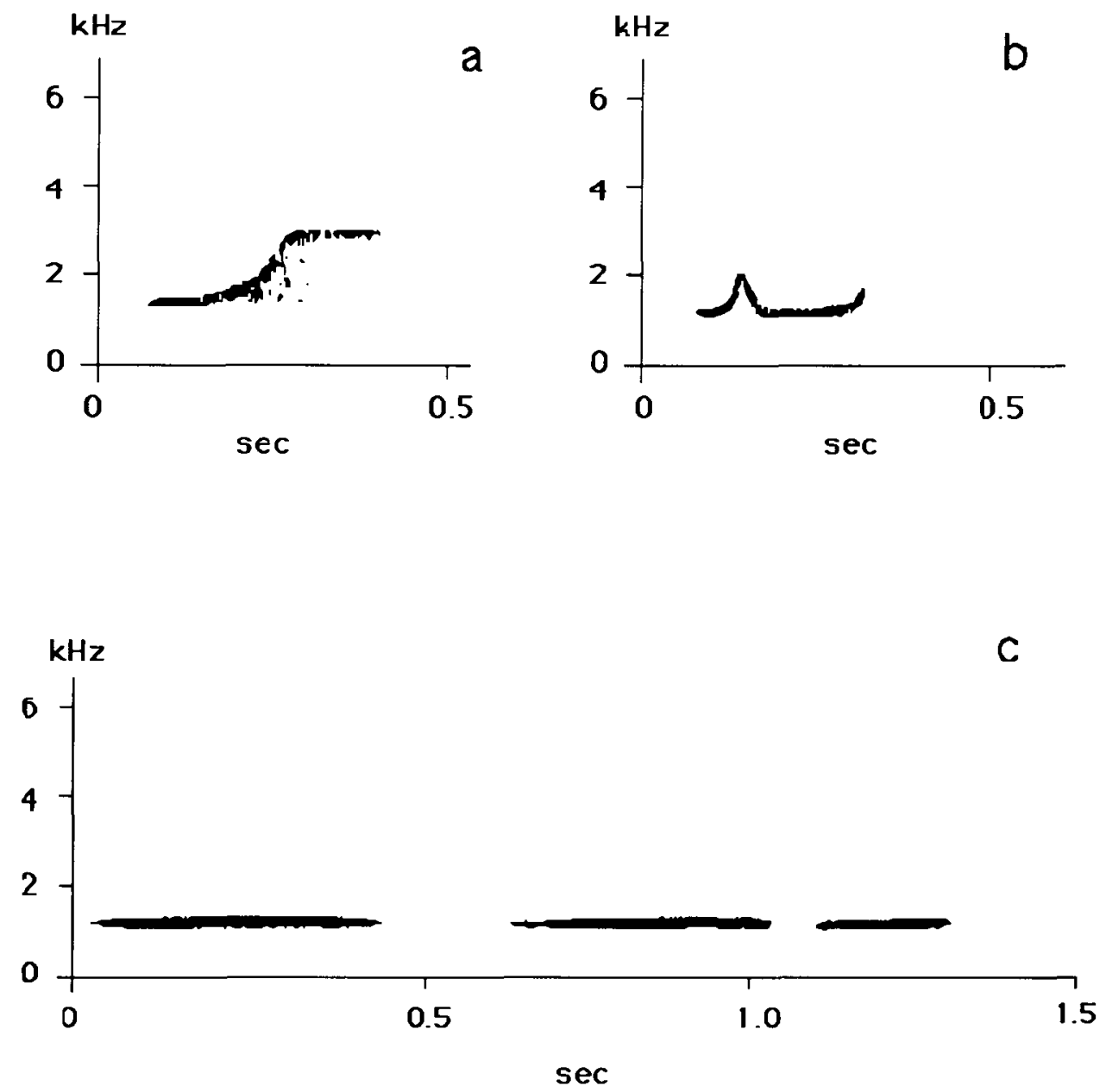

Figure 2. Sonagrams of songs of selected Crypturellus tinamous, (a) C. transfasciatus (Peru: Tumbes; T. A. Parker recording, from LNS), (b) C. atrocapillus (Peru: Cuzco; LNS 3007o), (c) C. erythropus (Venezuela: Cojedes; LNS 00830).

given by Schulenberg and Parker (1981) and Wiedenfeld et al. (1985). [For comparable information on the species in Ecuador, see Best (1992) and Parker and Carr (1992).]

The relationships of species within the genus Crypturellus have been obscure, owing to the similarities in plumage between many taxa. One particularly difficult group has been the set of species that includes cinnamomeus, erythropus and noctivagus (Hellmayr and Conover 1942, Meyer de Schauensee 1966, Blake 1977). The taxon atrocapillus, of south-western Amazonia, has been considered conspecific with C. noctivagus of eastern Brazil (Hellmayr and Conover 1942) or with C. erythropus of northern South America (Meyer de Schauensee 1966). Crypturellus atrocapillus shares with cinnamomeus and transfasciatus a simple, monosyllabic song; in contrast, $C$. erythropus and noctivagus utter lower-pitched songs of three or more hollow whistles (Figure 2). Although $C$. atrocapillus 
closely matches noctizagus in size and overall appearance, these vocal differences support recent treatments of the two as separate species (Blake 1977, Hilty and Brown 1986). The late Paul Schwartz (verbally to T.A.P., Hilty and Brown 1986) believed that $C$. noctivagus and $C$. erythropus (including idoneus, columbianus and saltuarius) were closely related, based on vocal characters. The structurally simple song of $C$. atrocapillus (in addition to zoogeographic considerations) may link C. cinnamomeus and C. transfasciatus with the erythropus complex.

\section{Grey-backed Hawk Leucopternis occidentalis}

Wiedenfeld et al. (1985) obtained the first Peruvian records of this species at El Caucho and Campo Verde in 1979, and M.K. saw a pair there in late February 1986. In late July 1988, T.A.P. and W.H.W. observed at least two pairs and a subadult in three widely separated localities C. 5 and $15 \mathrm{~km}$ south-west of El Caucho along the road to Pampas de Hospital, and in Quebrada Faical c. $5 \mathrm{~km}$ north-east of El Caucho. The Faical pair, one of which carried a $4 \mathrm{~cm}$ long teiid lizard, circled low over semi-deciduous forest with a closed canopy in a fairly humid canyon (elevation $\mathrm{c} .750 \mathrm{~m}$ ), whereas the other three were recorded in drier, more open Eriotheca-dominated forest at a lower elevation (c.500 m). One flying adult repeatedly uttered a short, raspy scream. The occurrence of $L$. occidentalis in low-elevation deciduous forest in the Bosque Nacional de Tumbes suggests that it may occur in numbers south-west of the Rio Tumbes in the Parque Nacional Cerros de Amotape, and perhaps even farther south into the department of Piura.

\section{Short-tailed Hawk Buteo brachyurus}

This species was listed for Campo Verde by Wiedenfeld et al. (1985). We found it to be relatively common in evergreen forest on the slopes of Cerro San Carlos and along the Campo Verde-Cotrina trail (at c. $700-800 \mathrm{~m}$ ), where at least three light- and two dark-phase adults were seen circling and hovering over forest on 25-27 July 1988. The species was known to occur in western Ecuador south to Piñas, El Oro province (Robbins and Ridgely 1990).

\section{Black Hawk-eagle Spizaetus tyrannus}

M.K. flushed one from a tree along the road to Figueroa, and T.A.P. and W.H.W. saw single adults near Cotrina and circling high over the southern end of Cerro San Carlos on 26 and 27 July 1988, respectively. This species was first found in western Peru at Campo Verde in 1979 (Wiedenfeld et al. 1985). We doubt that many other areas west of the Andes and south of extreme north-west Ecuador support viable populations of this or other large raptors known from the Bosque Nacional, among which are Sarcoramphus papa (which is common), Accipiter bicolor, Buteo albonotatus, Leucopternis occidentalis, Buteogallus urubitinga, Geranospiza caerulescens and Micrastur semitorquatus.

\section{Barred Forest-falcon Micrastur ruficollis}

Three different individuals were heard (LNS) at first light on 27 July 1988 in evergreen forest between Cotrina and Campo Verde. Their "songs", series of 
evenly spaced yelps, were very like those of populations east of the Andes. Our records presumably are of $M . r$. interstes, which has been collected as near as Piñas, El Oro, south-western Ecuador (Robbins and Ridgely 1990, M. B. Robbins in litt. 1994). Micrastur semitorquatus was heard at the same time and place.

\section{Rufous-headed Chachalaca Ortalis erythroptera}

This endemic cracid was inexplicably scarce (or perhaps much more furtive than other members of the genus) in evergreen forest at Campo Verde-Cotrina. Two pairs were counter-calling well before dawn (05h15) on 27 July 1988 in dense forest near Cotrina. Their duets were noticeably slower and lower-pitched than those of other Ortalis known to us (LNS). Another pair was seen in slightly drier forest on Cerro San Carlos on the same day. T.A.P. and W.H.W. were also shown one of two birds shot along a small stream by a soldier at Campo Verde. Wiedenfeld et al. (1985) found this species in drier forest near El Caucho, but in 1988 soldiers at the military post said that they had not seen the species there within the last two years. In late February 1986, M.K. heard up to four flocks daily along the trail between El Caucho and Figueroa; at this time of year, the breeding season, chachalacas may be more vocal.

As with numerous other species endemic to western Ecuador and northwestern Peru, the Bosque Nacional of Tumbes probably supports one of the largest populations of this species, but further work is needed to determine its true status there. [The species is now known to be more widespread in western Ecuador, and is locally common: see Best (1992), Parker and Carr (1992), Best and Krabbe (1994).] The Peruvian distribution of $O$. erythroptera is usually reported as "Tumbes and Piura" (Koepcke and Koepcke 1966, Meyer de Schauensee 1966, Blake 1977). The only other locality reported from within Peru is Paletillas (Chapman 1926), which is, however, a locality in Ecuador (Paynter 1993). Thus its known Peruvian range is limited to the Bosque Nacional de Tumbes along the Ecuadorian border.

\section{Penelope sp.}

Soldiers at Campo Verde and Cotrina, and cattle-herders who regularly use the trails in the area, report the presence of a large, black guan in evergreen forest along the Ecuadorian border. Several of these informants were certain that the birds have white flight feathers as in P. albipennis, but their memory of them might have been influenced by an ICBP poster of that species on display at the El Caucho military post. Nonetheless, we are convinced that a large guan does occur in the area, either $P$. purpurascens, known from within $50-60 \mathrm{~km}$ of the border at El Chiral, Ecuador (Chapman 1926), or P. albipennis, originally described from Tumbes.

\section{Rufous-necked Wood-rail Aramides axillaris}

On 26 February 1986 at El Caucho, M.K. was drawn to an irregular clicking noise, very much like the pecking of a large woodpecker, in a forest ravine, 
and found an adult $A$. axillaris with at least four downy, all-black chicks. As he approached, the adult dashed towards him displaying the rufous in the wings by spreading them sideways, and while grunting and squeaking, approached to within $1.5 \mathrm{~m}$. This attracted a second adult, which gave similar displays, while the first bird, uttering the clicking notes, led the chicks away. As M.K. retreated, the second bird followed him for about $50 \mathrm{~m}$. After it stopped following, M.K. twice heard a call that was composed of two parts, a loud, highpitched queeng (somewhat similar in quality to the song of $A$. cajanea), followed by a much deeper, less audible booming sound. M.K. later observed a pair with one chick in another area, and also once saw three adults accompanied by a single chick. On other occasions he heard the clicking, grunting and squeaking noises as well as the rustling of large birds running on the ground.

T.A.P. and W.H.W. found A. axillaris to be fairly common in mangroves $0.5 \mathrm{~km}$ south of Puerto Pizarro on 21-22 July 1988. As many as nine were counted at once as they foraged on mudflats exposed during low tide. The birds generally stayed within a few metres of mangroves, but occasionally ventured up to $15 \mathrm{~m}$ from cover. They appeared to be feeding on small crabs. Several were studied for up to 10 minutes at a time, when their field marks were clearly noted, including the rufous head, neck and breast; olive upperparts; black tail and undertail coverts; greenish bill; and red legs. Although not previously reported from Peru, the discovery of populations of A. axillaris south of Ecuador was not unexpected. Chapman (1926) gives records from coastal mangroves and forested areas as high as $600 \mathrm{~m}$ in extreme south-western Ecuador. Strangely, T.A.P. and W.H.W. did not see or hear any Rallus longirostris, easily found by T.A.P. in the Puerto Pizarro mangroves during a brief visit in late November 1974; M.K. saw a single R. longirostris here on 21 February 1986.

\section{Scaled Pigeon Columba speciosa}

M.K. observed this unmistakable species in the Campo Verde area almost daily in late February 1986. On three occasions individuals were seen during early morning perched conspicuously atop broken-off branches of tall dead trees, and he once watched a flock of 8-10 feeding in a fruiting tree. He also recorded up to 10 large columbids flying singly or in pairs over forest every day, and identified at least three of them as Scaled Pigeons. This species was not previously known on the Pacific slope of South America south of Chone, Ecuador (Chapman 1926). [Recently recorded in Machalilla National Park, Manabí, Ecuador; see Parker and Carr (1992).] Our failure to find this pigeon during the dry months of June-July suggests that it may occur in north-western Peru only during the wet season (December-April).

\section{Ruddy Pigeon Columba subvinacea}

This species (presumably C. s. berlepschi) was heard and seen several times at Cotrina and Campo Verde in the canopy of evergreen forest. The songs of these birds were indistinguishable to T.A.P.'s ear from those of Amazonian subvinacea, but were distinctly faster and slightly higher-pitched than those of C. plumbea (wup-puboo-boo of subvinacea vs. whoo-whu-whooo of plumbea). This is the first 
report of C. subvinacea west of the Andes in Peru, although it had been recorded at Alamor in adjacent south-west Ecuador (Chapman 1926). The report of $C$. plumbea at Campo Verde (Wiedenfeld et al. 1985) may in fact have been based on misidentified subvinacea.

\section{Ochre-bellied Dove Leptotila ochraceiventris}

This little-known dove was not recorded during the June-July 1979 survey of the El Caucho area by Wiedenfeld et al. (1985); these workers, however, spent only two field days at the more humid Campo Verde site, where the species might be more likely to occur. M.K. found it to be common at Campo Verde in late February 1986, when groups of 3-7 (and rarely single birds or pairs) were flushed from the ground in trail-edge forest; 15-30 were seen daily.

In late July 1988 T.A.P. and W.H.W. found L. ochraceiventris in small numbers (up to six in one morning) in forest on the west slope of Cerro San Carlos at c. $750 \mathrm{~m}$. The birds were flushed singly from the shaded floor of semi-deciduous forest not far from the slightly more humid evergreen forest of Campo Verde (where none was found). In the same area, they noted much larger numbers of $L$. verreauxi (abundant in all localities visited), several small groups (2-6) of Claravis pretiosa, and pairs or small groups of Columbina buckleyi, all of which foraged on the ground at the overgrown, weedy edges of the trail. Such a concentration of columbids in this "transitional" forest might be a seasonal phenomenon. The year-round movements and habitat requirements of L. ochraceiventris in Tumbes remain undetermined. [See Best (1992) for a discussion of movements in Ecuador.] The species is known from several localities in southwest Ecuador (Chapman 1926, Robbins and Ridgely 1990, Best and Clarke 1991, Best 1992, Parker and Carr 1992) and from Palambla in Piura, Peru (Meyer de Schauensee 1966). Semi-humid forests in the latter locality have been almost totally destroyed, but suitable habitat may occur in less densely settled areas to the north and south.

\section{Grey-cheeked Parrot Brotogeris pyrrhopterus}

Small flocks (of c.6-10 individuals) and pairs of this small parrot, endemic to the Tumbesan region, were very conspicuous in the drier forest at El Caucho and in Quebrada Faical; estimated daily counts within $5 \mathrm{~km}$ of the military post were of 60-120 individuals. Many of these fed on the flowers and seeds of large trees including an Erythrina sp., Chorisia sp. (Bombacaceae), and Cavanillesia platanifolia (where seen probing at flowers). They also ate fruits of a Ficus sp., and catkins of a Cecropia sp. They chattered noisily while foraging; their vocalizations are very similar to those of Brotogeris jugularis and B. cyanoptera. The species was scarce (<10 recorded daily) in the greener forest at Campo Verde and Cotrina, where fewer flowering trees were in evidence. Seasonal movements are likely.

Although this small parrot survives in moderate numbers in the El Caucho area, we are concerned about the effects that the pet trade may have on its populations. Data on trade in this species are difficult to evaluate, however. Over 40,000 were reported to have been imported into the United States in 
1984-1988 (Mulliken and Thomsen 1990), most if not all of them listing Peru as the country of origin. The population of B. pyrrhopterus within its limited distribution in Peru is nowhere near large enough to support this level of trade, suggesting a massive effort to smuggle this species from Ecuador to Peru for exportation. Alternatively, it is possible that at least some of the birds imported as $B$. pyrrhopterus were in fact Amazonian species such as $B$. versicolurus or $B$. cyanoptera (see Best et al. 1995, this issue). Nonetheless, it is clear that some large shipments of B. pyrrhopterus have reached the U.S.A. (Harris 1985).

\section{Bronze-winged Parrot Pionus chalcopterus}

Almost nothing has been published on the Peruvian population of this species, which has declined throughout its range as a result of deforestation (Ridgely 1981). It is considered local and nomadic in Colombia (Hilty and Brown 1986), where it is mainly recorded in humid montane forest from 1,400 to $2,400 \mathrm{~m}$. On the Pacific slope of Ecuador it remains locally common but threatened by rapidly ongoing habitat destruction (T.A.P., pers. obs.). In late February 1986, M.K. noted $30-50$ P. chalcopterus daily (mainly in groups of $2-8$, occasionally up to 18 ), along the El Caucho-Campo Verde trail. In late July 1988, T.A.P. and W.H.W. found this parrot in smaller numbers in evergreen forest at Campo Verde and Cotrina, where it was heard or seen primarily late in the afternoon as pairs and small flocks of 4-10 birds flew towards a roost somewhere east of the Cotrina military post. T.A.P. and W.H.W. estimated the local population to be under 100 individuals in mid-1988, although the population in the Bosque Nacional may number several hundred. Other July 1988 records include a flock of 12 seen high over a ridge in dry deciduous forest south of El Caucho, and eight feeding on the fruits of a Guazuma ulmifolia (Ulmaceae) in transitional forest on Cerro San Carlos. Several others were flushed from a fruiting Ficus $\mathrm{sp}$. in the same area.

The degree to which this species wanders in and out of the national forest is unknown. M.K.'s observations suggest that larger numbers occur during the wet season (December-April). Considering the limited amount of evergreen forest south of the Río Tumbes, however, we doubt that more than $500 P$. chalcopterus occur within Peru at any one time.

\section{Crowned Woodnymph Thalurania colombica hypochlora}

Several female-plumaged hummingbirds seen in the undergrowth of evergreen forest at Cotrina had grey underparts and white-tipped, blue outer tail feathers, and were probably hypochlora. This woodnymph, which is apparently allopatric from other woodnymphs and may deserve species status (Robbins and Ridgely 1990), was known from several localities in adjacent south-west Ecuador (Chapman 1926, Robbins and Ridgely 1990) but not previously recorded from Peru. Two very similar-looking species, the smaller Damophila julie and the larger Chalybura buffonii, were also recorded in small numbers at Campo Verde (Wiedenfeld et al. 1985) and Cotrina (pers. obs.), the only known Peruvian localities for them. All three species may be restricted in Peru to the forested ridges north of the Río Tumbes. 


\section{Olivaceous Piculet Picumnus olivaceus}

A single individual (presumably P. o. harterti) was seen by T.A.P. in forest at Cotrina, as it foraged along slender branches and vines in the upper canopy as part of a mixed-species flock. The greenish back and unmarked, pale underparts were noted; this is the only species of piculet found west of the Andes with these characteristics. The song was a descending trill. This is the first record of Olivaceous Piculet from Peru, although it has been collected within $20 \mathrm{~km}$ of the border in Loja, Ecuador (Chapman 1926).

\section{Olivaceous Woodcreeper Sittasomus griseicapillus aequatorialis}

This small dendrocolaptid was common in both deciduous and evergreen forests at all three localities. One or two individuals were noted with each large mixed-species flock at all heights, especially on trunks and larger limbs, from which small insects were gleaned. The primary song of this geographically isolated population is markedly different from that of the Amazonian forms of griseicapillus with which we have experience (amazonus, axillaris and viridis). It consists of a 3-4 second long trill that ascends slightly and decreases noticeably in volume (Figure 3 b). Amazonian birds utter a more complex rising and accelerating series of well-spaced, short whistles that taper off in volume and drop slightly in pitch towards the end (Figure 3a). Populations of south-eastern Brazil, eastern Paraguay and north-eastern Argentina (sylviellus) give yet different vocalizations, an explosive, somewhat bouncy, series of sharp notes (primary song?; Figure $3 \mathrm{c}$ ), and a slower, descending series of notes (Figure $3 \mathrm{~d}$; see also Belton 1984). Some populations differ in plumage as well, especially the very olivaceous sylviellus. A full review of vocal, morphological and genetic variation within Sittasomus, which is beyond the scope of this paper, is needed to clarify the relationships of the various taxa; we strongly suspect that more than one species is involved.

\section{Rufous-necked Foliage-gleaner Syndactyla ruficollis}

This species was considered rare at El Caucho by Wiedenfeld et al. (1985). It was inconspicuous and apparently uncommon in evergreen forest between Campo Verde and Cotrina, where five different individuals were recorded on $26 \mathrm{July}$ 1988. All of these were with or near mixed-species flocks at mid-heights or in the canopy, where they searched mosses and bromeliads on large limbs and branches, unlike true Automolus, which are specialized dead-leaf searchers (Remsen and Parker 1984). The species has a wider elevational range (c.500$2,900 \mathrm{~m}$ ) than most of the endemics discussed in this paper, but is equally at risk. The primary song was described by Parker et al. (1985), and is here shown in comparison with the homologous vocalization of Syndactyla rufosuperciliata (Figure 4); see Parker et al. (1985) for a brief discussion of the similarities in the song between $S$. ruficollis and $S$. rufosuperciliata, and for our reasons for placing ruficollis in the genus Syndactyla (rather than in Automolus). 


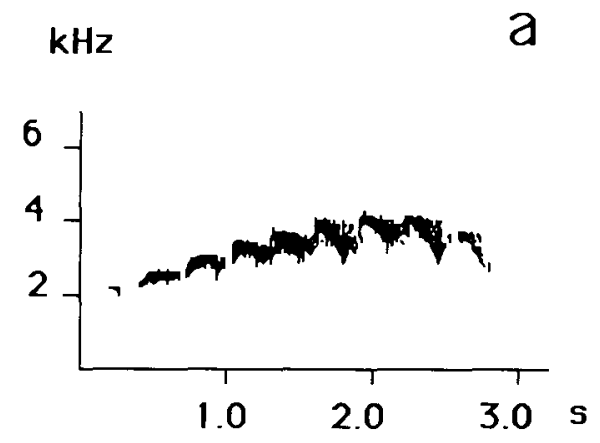

\section{$\mathrm{kHz}$}

b

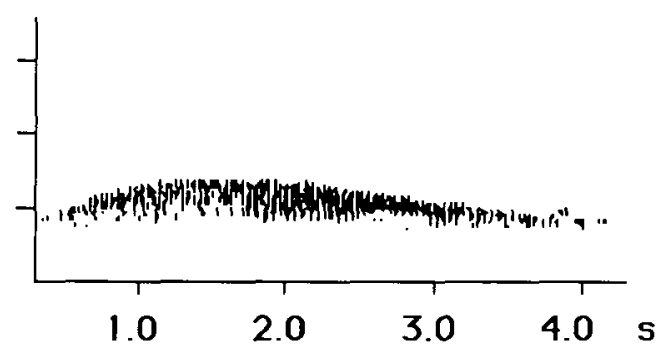

$\mathrm{C}$

$\mathrm{kHz}$
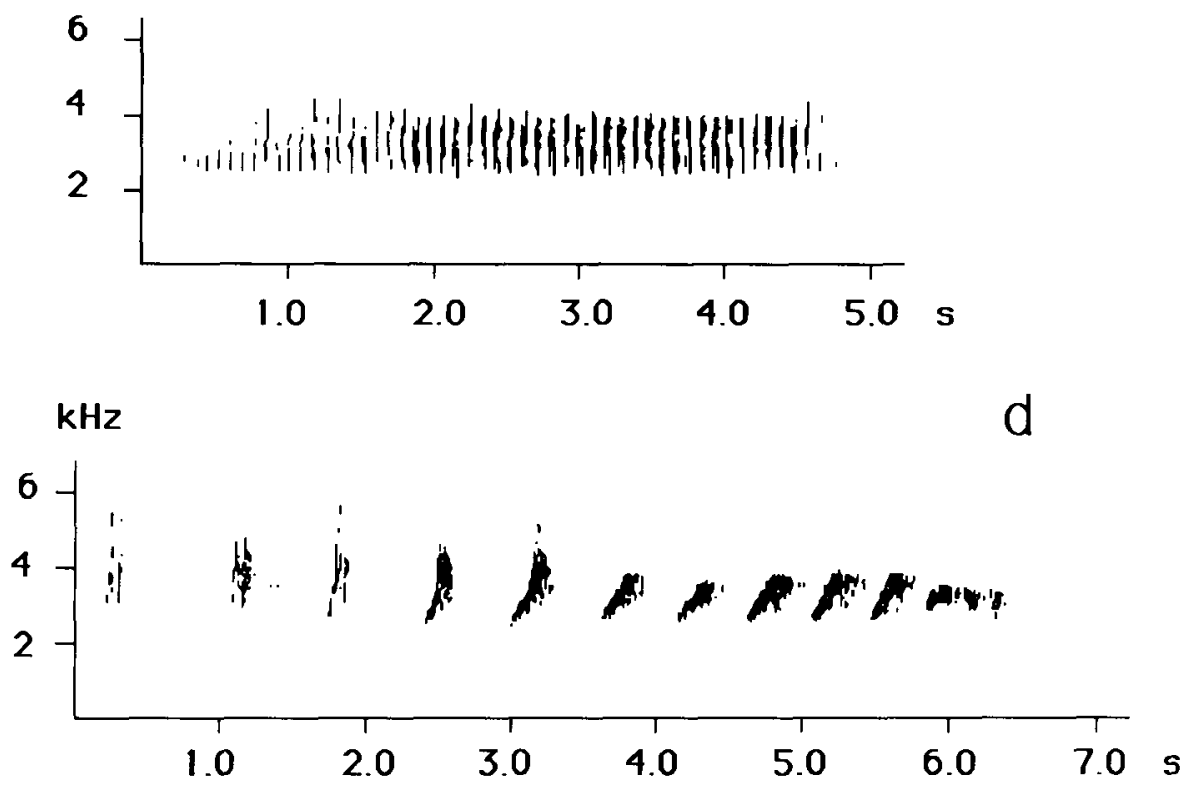

Figure 3. Sonagrams of songs of selected populations of Sittasomus griseicapillus. (a) S. griseicapillus amazonus (Peru: Madre de Dios; LNS 24111), (b) S. griseicapillus aequatorialis (Ecuador: Esmeraldas: T. A. Parker recording, from LNS), (c) S. griseicapillus sylviellus (Brazil: Rio Grande do Sul; LNS 19070), (d) S. griseicapillus sylviellus (Brazil: Rio Grande do Sul; LNS 19076).

Henna-hooded Foliage-gleaner Hylocryptus erythrocephalus

Recent records and notes on the behaviour of this peculiar furnariid were given by Paynter (1972), Schulenberg and Parker (1981), Wiedenfeld et al. (1985) and Best and Clarke (1991). It inhabits evergreen and semi-deciduous forest within an elevational range of c.600-1,800 m on the western slope of the Andes from south-west Ecuador at $3^{\circ} \mathrm{S}$ to north-west Peru at $6^{\circ} \mathrm{S}$. [Recently found as far north in Ecuador as Machalilla National Park, C. $2^{\circ} \mathrm{S}$; see Parker and Carr (1992).] 

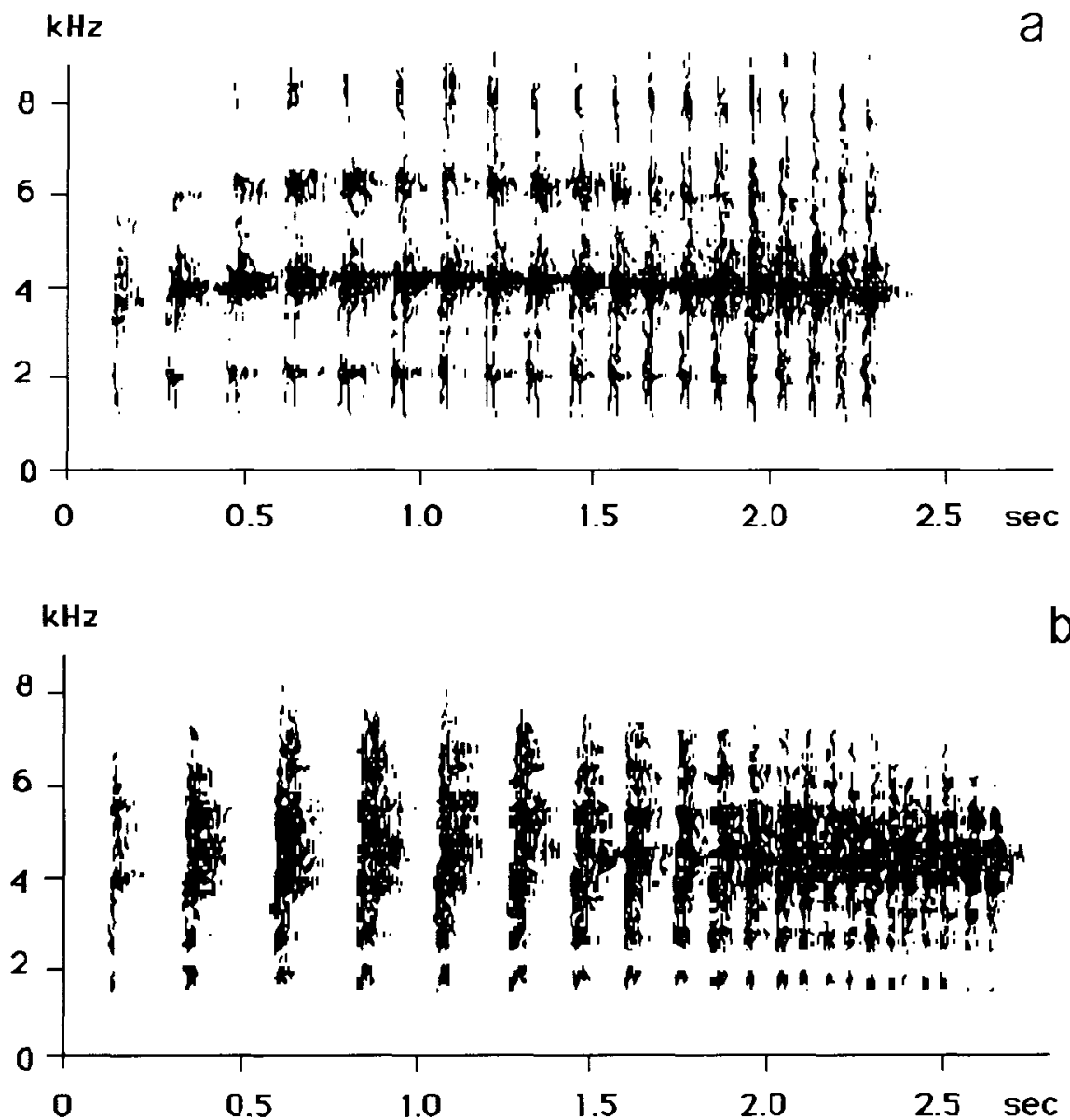

Figure 4. Sonagrams of songs of selected foliage-gleaners. (a) Syndactyla ruficollis (Peru: Piura; LNS 21871) (b) Syndactyla rufosuperciliata Bolivia: La Paz; LNS 17161). The song of ruficollis is a short, raspy, accelerating series, like the songs of Syndactyla spp.

Only scattered patches of forest, few if any larger than 1,00o ha, remain within the Peruvian range of this and other endemic species (T.A.P., pers. obs. from the air in July 1988).

Hylocryptus erythrocephalus was surprisingly numerous in the Campo VerdeCotrina area in late July 1988. Single birds or pairs, either alone or with groundforaging emberizine finches (Atlapetes torquatus, Arremon aurantiirostris or A. abeillei) were found rustling in fallen leaves on the fully shaded forest floor; 12 were found in two hours along c. $1 \mathrm{~km}$ of trail.

Hylocryptus erythrocephalus was also noted under dense undergrowth in shaded ravines at El Caucho. Individuals vigorously flipped aside leaves to uncover prey, often spending many minutes in an area of only a few square metres. When alarmed, they hopped up onto vines or trunks, perching horizontally or clinging almost vertically, and nervously flicked open both wings simultaneously, occasionally also flipping the tail upwards. Low tic or tuk notes 
were given, usually in short series. The apparent advertising song of the species is comprised of six notes. What is almost surely the largest remaining population of this species occurs on the forested ridges between the Río Tumbes and the Ecuadorian border.

\section{Plain Xenops Xenops minutus}

This species was seen twice with mixed-species flocks (which included Dysithamnus mentalis and Thryothorus sclateri) in forest understorey 1-3 $\mathrm{m}$ above the ground between Campo Verde and Cotrina. On both occasions the birds foraged in a fashion typical for the species: one was hanging vertically on a slender bamboo stalk, and the other tapped vigorously on slender dead vine stems. This is the first record of $X$. minutus from western Peru; X. $m$. littoralis had been reported from as far south as Piñas, El Oro (Robbins and Ridgely 1990). This xenops was greatly outnumbered in the Bosque Nacional by Xenops rutilans, which was common at mid-heights and in the canopy of deciduous as well as evergreen forest.

\section{Chapman's Antshrike Thamnophilus zarumae}

The occurrence of nominate zarumae at Campo Verde was documented by Wiedenfeld et al. (1985). We found the species to be rare at El Caucho in the more densely vegetated ravines, and uncommon from Cerro San Carlos to Cotrina in viny, evergreen forest. These antshrikes were found in pairs in dense tangles in both forest edge and interior, from within a few feet of the ground to as high as $12 \mathrm{~m}$, where twice noted with mixed-species flocks that included Sittasomus griseicapillus, Xenops rutilans, Dysithamnus mentalis, Thryothorus sclateri, Hylophilus minor and Basileuterus trifasciatus.

Unlike most forms of Thamnophilus doliatus, which inhabits forest edge and second growth, T. zarumae regularly, if not usually, occurs inside forest. This well-marked, isolated form is usually considered to be conspecific with $T$. doliatus, but for the reasons given below we regard zarumae as a separate species. The males of zarumae differ from males of most populations of doliatus by the reduction in the amount of the barring on the belly (T. zarumae is approached in this feature only by $T$. doliatus albicans and $T$. d. radiatus), and from adult males of all subspecies of $T$. doliatus by having buffy flanks and abdomen, and an unmarked grey collar. Females are similar in pattern to females of $T$. doliatus, but are paler than most populations of that species, and also have a grey collar. A comprehensive analysis of geographic and individual variation in the songs of $T$. doliatus is beyond the scope of this paper. We have, however, compared the song of zarumae to that of individuals of several subspecies from throughout the range of $T$. doliatus (Figure 5). Whereas the songs of doliatus characteristically terminate with a down-slurred waah, at the same frequency as or a little higherpitched than the rest of the song, the song of zarumae ends with a staccato series of several very broad-amplitude notes. The plumage differences between $T$. zarumae and all populations of $T$. doliatus make it clear that zarumae is a good phylogenetic species (sensu McKitrick and Zink 1988); the differences in song suggest that it is a valid biological species as well. 

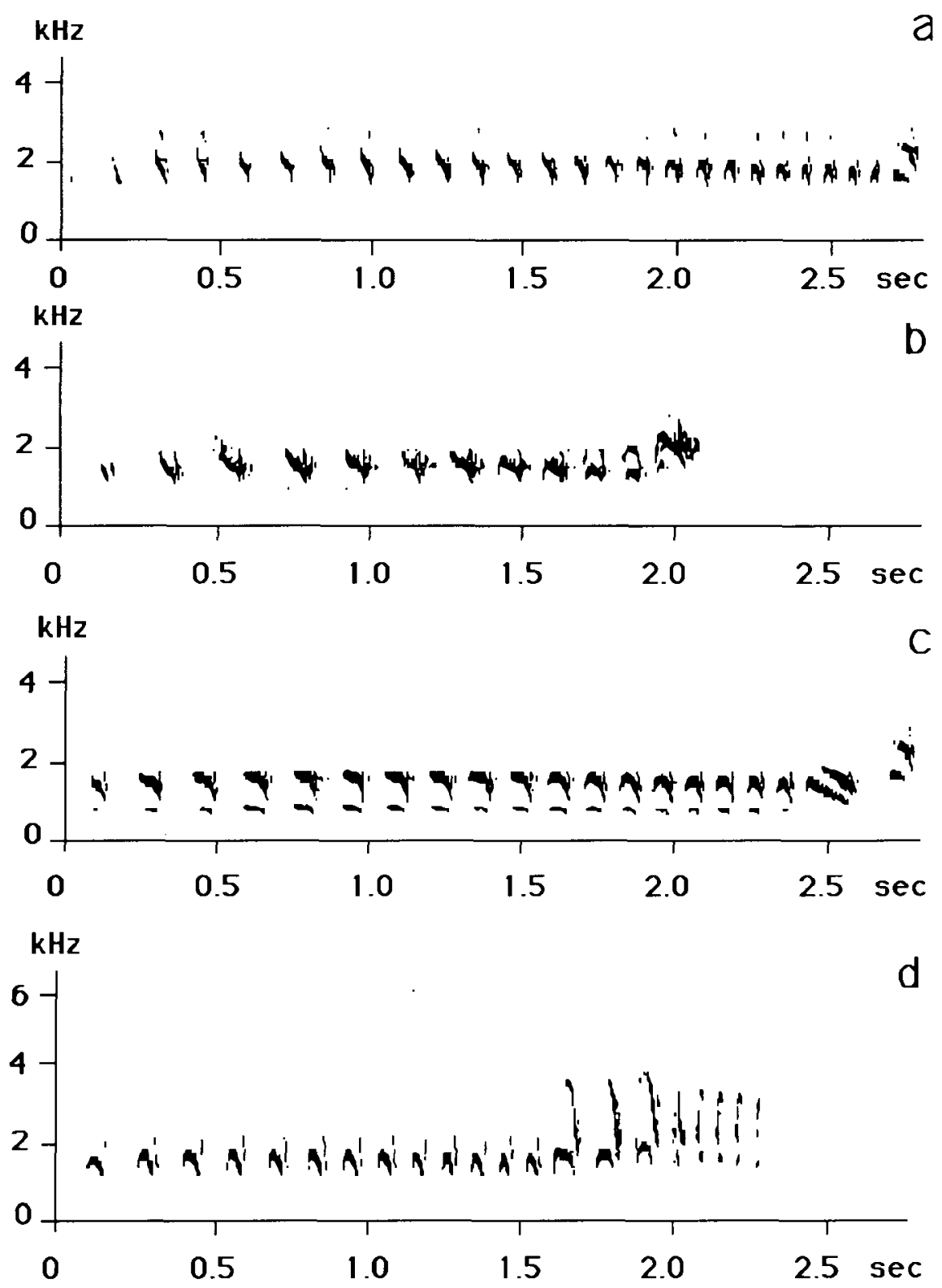

Figure 5. Sonagrams of songs of Thamnophilus zarumae and of selected populations of Thamnophilus doliatus. (a) T. doliatus nigricristatus (Panama: Panama; LNS 25606), (b) T. doliatus subradiatus (Peru: Madre de Dios; LNS 12861), (c) T. doliatus capistratus (Brazil: Bahia; LNS 35715), (d) T. zarumae (Peru: Piura; T. S. Schulenberg recording).

White-backed Fire-eye Pyriglena leuconota pacifica

The presence in Peru of this antbird was first reported by Wiedenfeld et al. (1985), based on a female collected at Campo Verde. In July 1988, T.A.P. and W.H.W. found the species to be common in dense undergrowth of evergreen 
forest in the Campo Verde-Cotrina area and on Cerro San Carlos. Fire-eyes were encountered in pairs, usually apart from other species, and always within $1 \mathrm{~m}$ of the ground in fully shaded vine tangles. They hopped deliberately from perch to perch, regularly lowering and slowly raising the tail as they scanned surrounding foliage and branches. Foraging manoeuvres included at least six perch-gleans of a slender branch and leaf stems, one $5 \mathrm{~cm}$ upward sally to a $4 \mathrm{~cm}$ diameter branch, and one $15 \mathrm{~cm}$ upward sally to, and brief hang on, a dead-leaf cluster. Pairs were vocal and responsive to playback of their own songs, which are rapid, descending series of about 12 whistles very like those of other members of the genus (Willis 1981, Willis and Oniki 1982, pers. obs.).

Currently 12 taxa are recognized in the genus Pyriglena (Peters 1951), although one of these (interposita) is probably not distinguishable from nominate leuconota (D. F. Stotz verbally 1988). Patterns of plumage variation are not concordant between the sexes. All taxa that have been studied have similar behaviours and songs, although at least some populations appear to have unique call notes in their vocal repertoires (Willis 1981, Willis and Oniki 1982). Three species are usually recognized (Cory and Hellmayr 1924, Peters 1951, Meyer de Schauensee 1966, Willis and Oniki 1982), but the complex has been treated as including anywhere from one (Zimmer 1931) to at least six (Chapman 1923) species. Pacifica is the only taxon in this group that occurs west of the Andes. It is slightly shorter-tailed than are the closest populations on the east side of the Andes (Chapman 1923), and is very different in female plumage, which is most similar to that of the geographically removed $P$. leucoptera of eastern South America. It is possible that pacifica merits recognition at the species level, although we refrain from changing the current taxonomy in the absence of a comprehensive review of the systematics of the genus.

\section{Watkins's Antpitta Grallaria zoatkinsi}

At El Caucho G. watkinsi was fairly common (by voice), but restricted to greener portions of forest, especially the shaded, denser vegetation of narrow ravines. In the wide valley south of El Caucho, as many as 12 individuals were heard at once (within a radius of $\mathrm{c} .600 \mathrm{~m}$ ) just before and at first light (o5h30-05h45), when the only other birds calling were owls. Thereafter, the species was almost silent until 18 hoo or later. On the brightly moonlit night of 27 July 1988 at least six individuals sang from $18 \mathrm{~h}_{45-19 h o o}$ in the wide ravine just north of $\mathrm{El}$ Caucho. Also calling were numerous Crypturellus transfasciatus, one (male?) Ciccaba nigrolineata, and several Glaucidium peruanum. The antpitta was not heard in the more open, drier forest on the upper slopes and ridges above or to the south of the military post, but was noted in smaller numbers (perhaps less vocal?) in the evergreen forest at Campo Verde and Cotrina. In the latter locality, one hopped along the edge of a recently burnt clearing bordering secondgrowth woodland, seemingly in association with a mixed flock of brush-finches and seedeaters. The known elevational range of watkinsi in Tumbes extends from c. 600 to $900 \mathrm{~m}$, whereas in nearby Ecuador it occurs in more humid evergreen forest as high as $1,400 \mathrm{~m}$.

Chapman (1919) described the characters that distinguish this little-known and geographically restricted species from Grallaria ruficapilla. He further noted 
that watkinsi replaces (and nearly overlaps with) ruficapilla at lower elevations on the same slope of the western Andes in extreme south-western Ecuador and adjacent northern Peru. We herein document vocal differences as well.

The geographically invariable advertising song of G. ruficapilla comprises three rich whistles: a short introductory note followed by two longer notes, the middle one being very slightly lower than the others (Figure 6a-d). In watkinsi song, these notes are shorter, higher-pitched, and much more closely spaced (Figure 6e), sounding like a single, protracted whistle with a noticeable introductory stutter. The most frequent call of ruficapilla is a short loud whistle given at intervals of 10 or more seconds. This vocalization seems to have no counterpart in the repertoire of watkinsi. Males and females of watkinsi deliver a descending series of up to eight evenly spaced notes and then the other bird begins to sing antiphonally at a slightly higher pitch. In view of these vocal differences, the lack of evidence for intergradation where watkinsi approaches ruficapilla, and the morphological differences described by Chapman (1919), we recommend treatment of watkinsi as a full species.

\section{Grey-breasted Flycatcher Lathrotriccus griseipectus}

Nothing has been published on the behaviour or status of this species, known from a small number of specimens from extreme south-western Ecuador and adjacent Peru, both on the Pacific slope south to Lambayeque on the west slope and in the upper Río Marañón valley to northern Cajamarca (Traylor 1979). Although not recorded in the Bosque Nacional of Tumbes by Wiedenfeld et al. (1985), in June 1988 T.A.P. and W.H.W. found it at Campo Verde and Cotrina in the shaded, vine-covered understorey of evergreen forest at $600-750 \mathrm{~m}$. One was also found at El Caucho in a densely forested ravine surrounded by drier and more open deciduous forest. One bird watched for at least 20 minutes near Cotrina employed a variety of foraging manoeuvres as it perched 3-5 $\mathrm{m}$ above the ground on slender vines and branches of small, partially sunlit trees in forest about $20 \mathrm{~m}$ tall. It made short, aerial sallies of $15-35 \mathrm{~cm}$ into a sunlit gap, and $5-20 \mathrm{~cm}$ sallies to leaves, stems and branches within a small area of $5 \mathrm{~m}^{2}$. The bird at Cotrina uttered two types of vocalization, a rather burry zeer-zeer (Figure $7^{b}$ ) or, less frequently, a series of four to five similar notes. In response to playback of these calls, the bird emphatically flicked its drooping and slightly opened wings, while holding its tail straight back. While foraging, it perched more upright, with the tail held vertically.

Vocalizations of L. griseipectus are very similar in structure and pattern to those of L. euleri (Figure 7 a), a tyrannid occurring throughout much of South America east of the Andes. Lanyon and Lanyon (1986) mentioned the need for anatomical specimens and tissue of this little-known species to determine its systematic affinities, but did not discuss the similarity of griseipectus to euleri. These two species are very similar in pattern, colour and size; griseipectus differs from euleri mainly in having a grey (vs. olivaceous) crown and whitish (vs. ochraceous) wing-bars and a whiter throat. Griseipectus is usually placed in the genus Empidonax; considering these morphological and vocal similarities, however, we believe that griseipectus is probably a grey allospecies in the euleri complex that colonized the arid Pacific slope of the Andes via the Marañon 

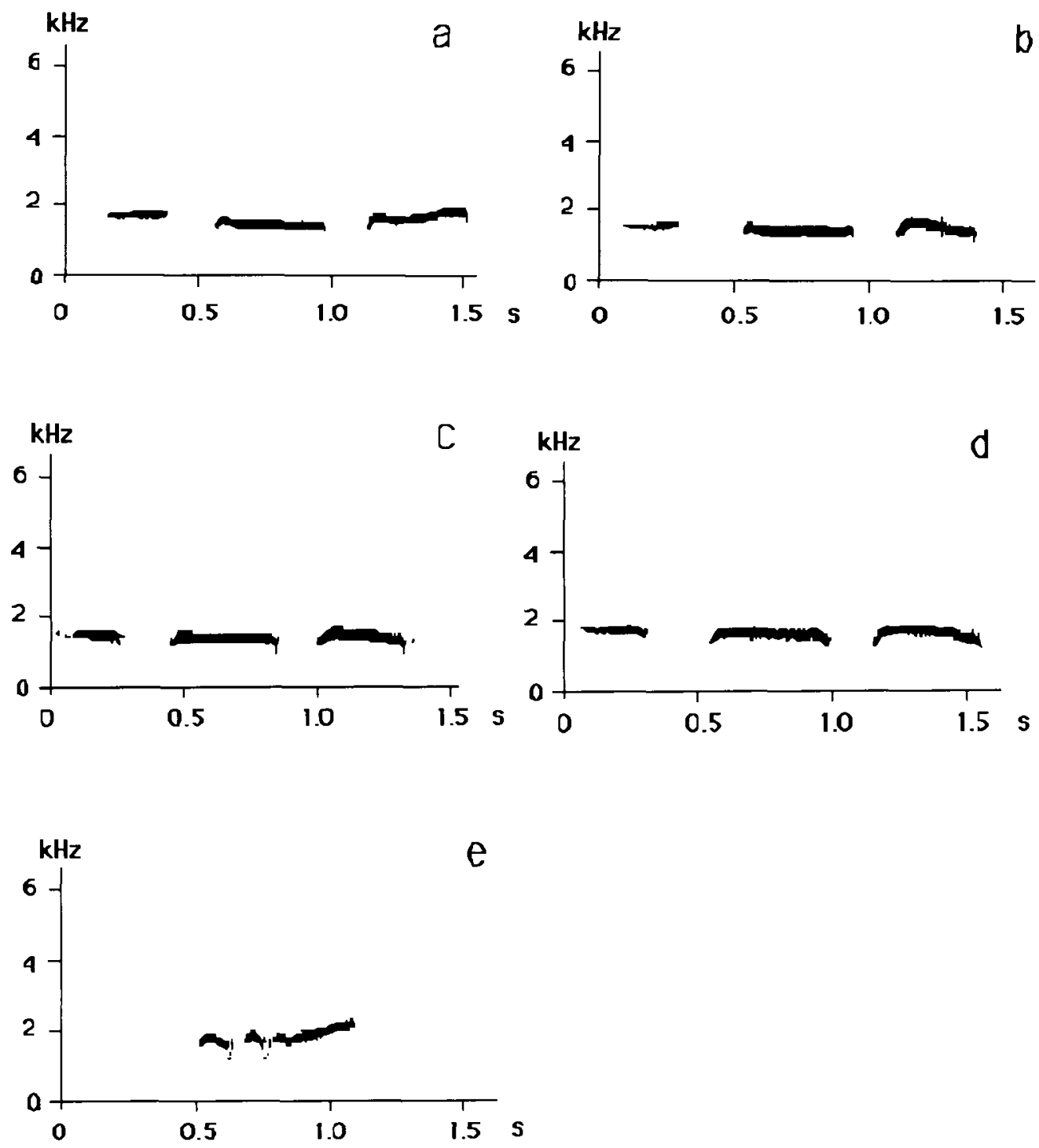

Figure 6. Sonagrams of songs of Grallaria ruficapilla and Grallaria watkinsi. (a) G. ruficapilla avilae (Venezuela: Aragua; LNS 07086), (b) G. ruficapilla ruficapilla (Ecuador: Pichincha; T. S. Schulenberg recording), (c) G. ruficapilla interior (Peru: Amazonas; LNS 18068), (d) G. ruficapilla albiloris (Peru: Piura; LNS 17595), (e) G. watkinsi (Peru: Tumbes; T. A. Parker recording, from LNS).

Valley. We recommend that it be placed in the genus Lathrotriccus unless additional evidence dictates otherwise.

This species appears to be threatened by rapid deforestation and would benefit from the protection of evergreen forest patches within the dry forest zone at low elevations $(600-900 \mathrm{~m})$ on the western slope of the Andes in south-west Ecuador and north-west Peru. A survey of the Marañon Valley population of this and other dry forest species is also recommended. Lathrotriccus griseipectus 

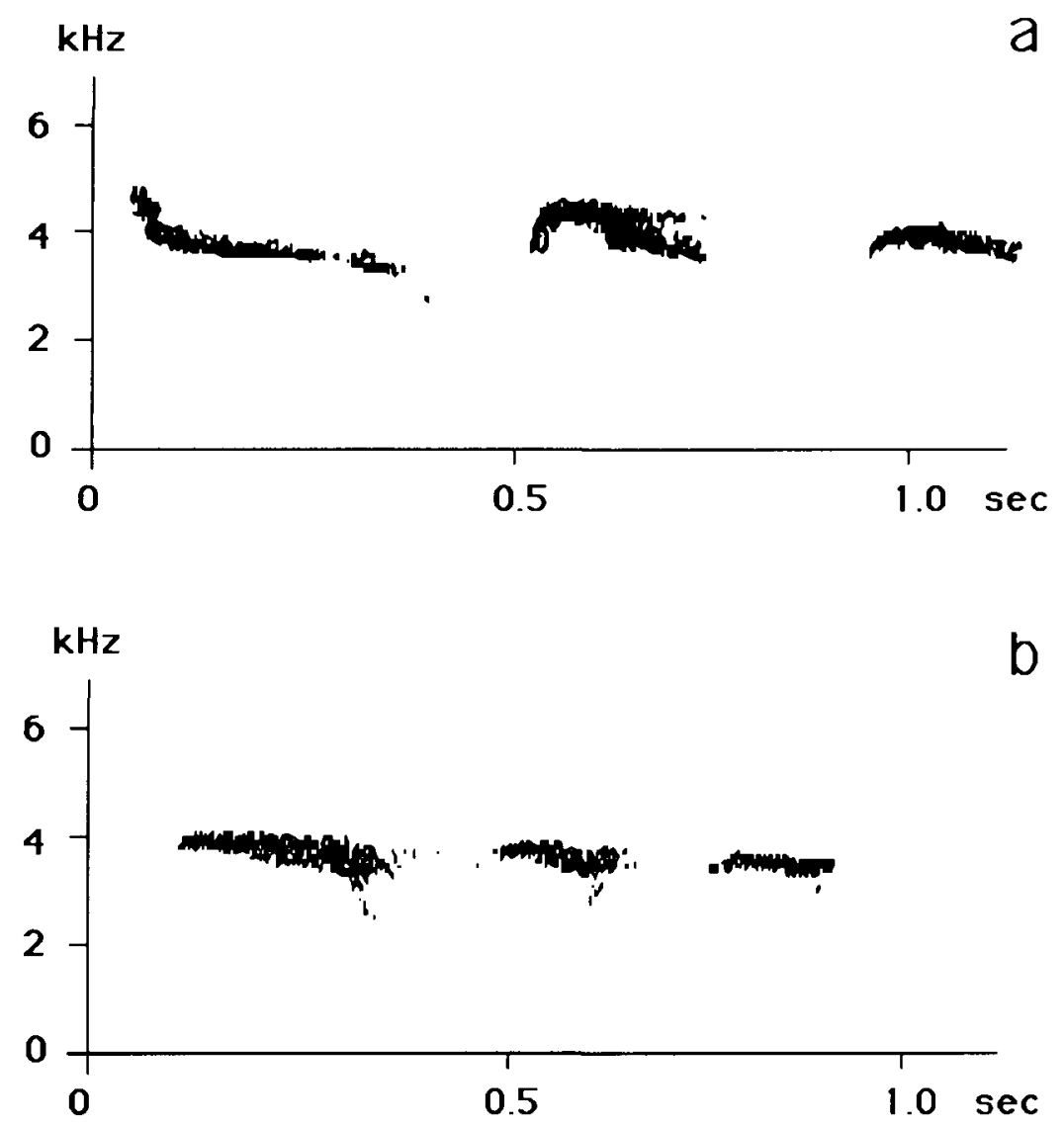

Figure 7. Sonagrams of songs of Lathrotriccus euleri and Lathrotriccus griseipectus. (a) L. euleri (Peru: Madre de Dios; LNS 29888), (b) L. griseipectus (Peru: Tumbes; T. A. Parker recording, from LNS).

has also been found in semi-deciduous forest at $700-800 \mathrm{~m}$ on the west slope of the Cordillera Condor, north-east of Jaén, Cajamarca, just above the densely settled Marañón Valley (J. W. Fitzpatrick and J. P. O'Neill verbally). Thus both the Pacific and the Marañon Valley populations of this little-known species appear to be vulnerable to the threat of deforestation.

\section{Ochraceous Attila Attila torridus}

This beautiful attila was seen by T.A.P. on 27 July 1988 in evergreen forest at Cotrina. The typical call is a down-slurred, clear whistle similar to that of $A$. cinnamomeus of Amazonia, but louder and rather hawk-like. A vocalization given by an unseen bird, probably this species, at El Caucho on 23 July 1988 was a rising series of 4-5 short whistles with an upward inflection. Attila spadiceus, which could occur in Tumbes but has not been found there, gives a rising series of doubled notes. This is the first report of $A$. torridus in Peru; it is otherwise restricted to western Ecuador. It was previously known from within a 
few kilometres of the Peruvian border at Alamor (Chapman 1926). It remains vulnerable due to habitat destruction within its small range (Robbins and Ridgely 1990, Collar et al. 1992).

\section{Speckle-breasted Wren Thryothorus sclateri}

Birds of the race paucimaculatus were common in deciduous and evergreen forests in the Bosque Nacional de Tumbes. They were invariably observed in pairs or small (family?) groups of three to four individuals, usually in association with other species, including Dysithamnus mentalis and a variety of other small insectivores. Like many other Thryothorus wrens (Remsen and Parker 1984), this species spends most of its time (more than $75 \%$ ?) $1-3 \mathrm{~m}$ above the ground probing curled, dead leaves trapped in vine tangles or dense branches in search of insects and other small invertebrates. Individuals were also seen foraging in the following situations: (1) on the ground flipping leaves; (2) tapping on and probing into slender, rotting vines; and (3) probing epiphytic growth (including Tillandsia and the lichen Usnea) on limbs of huge bombacaceous trees up to $30 \mathrm{~m}$ above the ground. It clearly was not confined to dense forest undergrowth as are Middle American forms of maculipectus and rutilus (pers. obs.). Males and females sang antiphonally as in other Thryothorus. We have seen T. sclateri in denser, greener portions of dry forest as far south as Quebrada San Isidro, Lambayeque $\left(5^{\circ} 45^{\prime} \mathrm{S}\right)$, where it apparently occurs only above $600 \mathrm{~m}$. The species was previously known as far south as Palambla, Piura (Chapman 1926).

In an example of the "leap-frog" pattern of geographic variation (Remsen 1984), three populations of South American spot-breasted wrens (columbianus, paucimaculatus and sclateri) are separated from the morphologically similar Middle American $T$. maculipectus by the different-looking rutilus complex. Hellmayr (1934) treated maculipectus and rutilus as conspecific. Other authors have recognized two species, but have placed the disjunct South American spot-breasted wrens with either maculipectus (Meyer de Schauensee 1966, AOU 1983, Hilty and Brown 1986) or with rutilus (Paynter 1960); or, these populations have been treated as a third species (Ridgely and Tudor 1989). No recent author has as yet advocated that columbianus, paucimaculatus and sclateri each be regarded as a separate species, although that is another option. A thorough morphological, behavioural and biochemical study of the maculipectus/rutilus populations might illuminate species-level relationships within this complex.

\section{Ecuadorian Thrush Turdus maculirostris}

Wiedenfeld et al. (1985) first reported this species for Peru, finding it to be fairly common at El Caucho and Campo Verde. M.K. observed the species daily at Campo Verde in late February and early March. T.A.P. and W.H.W. saw only two individuals during their visit in late July, both at mid-height in evergreen forest along the Campo Verde-Cotrina trail; at that time it was greatly outnumbered by $T$. reevei. We follow Ridgely and Tudor (1989) in recognizing maculirostris as a species separate from the geographically remote $T$. nudigenis, differing primarily in the lesser amount of bare orange skin around the eye. Its call, a cat-like, upslurred eeeeeow, is like that of nudigenis (T.A.P., pers. obs.). 


\section{Black-striped Sparrow Arremonops conirostris}

One heard by T.A.P. in shrubby, forest-edge vegetation at Cotrina $(600 \mathrm{~m})$ uttered a typical Arremonops song: an accelerating series of slightly raspy psuck notes. This is the first Peruvian record of this finch, previously known from several Ecuadorian localities within $20 \mathrm{~km}$ of the Peruvian border (Chapman 1926).

\section{Saffron Siskin Carduelis siemiradzkii}

Three siskins, a female (LSUMZ 93838) and an unsexed female-plumaged individual (LSUMZ 93839) preserved as study skins and a fluid-preserved adult male (LSUMZ 91586), collected at El Caucho in 1979 (Wiedenfeld et al. 1985), represent the little-known C. siemiradzkii. These specimens differ from Ecuadorian and Peruvian specimens of $C$. magellanica examined in being very small (male, female, unsexed: wing chord 60, 55.5, $56.2 \mathrm{~mm}$; weight 10.2, 7.9, 6.9 g) and more uniformly (saffron) yellowish, especially on the face, throat and ventrum. The identification of the two study skins was also confirmed by Mark Robbins (in litt. 1994), who compared them directly against specimens of siemir$a d z k i i$ from Ecuador. In addition to the El Caucho records, T.A.P. and W.H.W. saw three flocks $(6+, 4,8)$ of small siskins in tall grass and weeds at forest edge near Cotrina, Campo Verde, and on Cerro San Carlos, at 600-750 m. Adult males in these flocks had more pronounced yellow nuchal collars and paler, more yellowish-green upperparts than $C$. magellanica. Based on the above records, we add C. siemiradzkii to the Peruvian list. The species is apparently restricted to a small area in south-western Ecuador and adjacent Peru, ranging from sea-level on Puna Island (Chapman 1926) to (at least) $700 \mathrm{~m}$ in foothills of the Andes.

\section{Acknowledgements}

We would like to thank Mark Robbins and Doug Stotz for their careful reviews of different drafts of the manuscript, Tyana Wachter and Isabel Plenge for assistance with the Spanish summary, and Greg Budney (Library of Natural Sounds) for responding to numerous requests for copies of tape-recordings. Jodi Sedlock produced the final version of Figure 1. T.S.S. is also very grateful to Jacqueline Goerck for providing copies of T.A.P.'s original field notes, which made it possible to complete this paper.

For Ted: "Such a long, long time to be gone, and a short time to be there" (Robert Hunter). 
Appendix. Birds of the Bosque Nacional de Tumbes.

\begin{tabular}{|c|c|c|c|}
\hline & $\begin{array}{l}\text { February- } \\
\text { March }^{a}\end{array}$ & July & $\begin{array}{l}\text { June- } \\
\text { July }\end{array}$ \\
\hline Crypturellus transfasciatus & $x$ & $x$ & $x$ \\
\hline Ardea cocoi & & & $x$ \\
\hline Casmerodius albus & & $x$ & \\
\hline Egretta thuia & & $x$ & \\
\hline Mycteria americana & & & $x$ \\
\hline Coragyps atratus & $x$ & $x$ & $x$ \\
\hline Cathartes aura & $x$ & $x$ & $x$ \\
\hline Sarcoramphus papa & $x$ & $x$ & $x$ \\
\hline Elanoides forficatus & $x$ & & $x$ \\
\hline Accipiter striatus & & & $x$ \\
\hline Accipiter bicolor & $x$ & & $x$ \\
\hline Geranospiza caerulescens & & $x$ & $x$ \\
\hline Letucopternis occidentalis & $x$ & $x$ & $x$ \\
\hline Buteogallus urubitinga & & $x$ & $x$ \\
\hline Parabuteo unicinctus & $x$ & $x$ & $x$ \\
\hline Buteo magnirostris & & $x$ & \\
\hline Buteo brachyurus & $x$ & $x$ & $x$ \\
\hline Buteo albonotatus & & $x$ & $x$ \\
\hline Polyborus plancus & & & $x$ \\
\hline Spizaetus tyrannus & $x$ & $x$ & $x$ \\
\hline Herpetotheres cachimnans & $x$ & $x$ & $x$ \\
\hline Micrastur ruficollis & & $x$ & \\
\hline Micrastur semitorquatus & & $x$ & \\
\hline Falco rufigularis & & $x$ & \\
\hline Ortalis erythroptera & $x$ & $x$ & $x$ \\
\hline Aramides axillaris & $x$ & & \\
\hline Columba speciosa & $x$ & & \\
\hline Columba subvinacea & & $x$ & \\
\hline Columba plumbea & & & $X ?$ \\
\hline Zenaida auriculata & & $X$ & $x$ \\
\hline Columbina buckleyi & & $x$ & $x$ \\
\hline Columbina cruziana & $x$ & & $x$ \\
\hline Claravis pretiosa & $x$ & $x$ & $x$ \\
\hline Leptotila verreauxi & $x$ & $x$ & $x$ \\
\hline Leptotila ochraceiventris & $x$ & $x$ & \\
\hline Aratinga erythrogenys & $x$ & $x$ & $x$ \\
\hline Forpus coelestis & & $x$ & $x$ \\
\hline Brotogeris pyrrhoptertis & $x$ & $x$ & $x$ \\
\hline Piontis chalcopterus & $x$ & $x$ & $x$ \\
\hline Coccyzus lansbergi & $x$ & $?$ & \\
\hline Piaya cayana & & $x$ & $x$ \\
\hline Crotophaga sulcirostris & & $x$ & $x$ \\
\hline Otus roboratus & & $x$ & $x$ \\
\hline Pulsatrix perspicillata & & $x$ & $x$ \\
\hline Glaucidium peruanum $^{\mathrm{d}}$ & & $x$ & $x$ \\
\hline Ciccaba nigrolineata & & $x$ & \\
\hline Nyctidromus albicollis & $x$ & & $x$ \\
\hline Streptoprocne zonaris & $x$ & $x$ & $x$ \\
\hline Chaetura cinereiventris & $x$ & $x$ & $x$ \\
\hline Chaetura brachyura & & $X$ & $x$ \\
\hline Panyptila cayennensis & & & $x$ \\
\hline Phaethornis superciliosus & $x$ & $x$ & $x$ \\
\hline Phaethornis griseogularis & & $x$ & $x$ \\
\hline
\end{tabular}


Appendix. (cont.)

\begin{tabular}{|c|c|c|c|}
\hline & $\begin{array}{l}\text { February- } \\
\text { March }^{a}\end{array}$ & July ${ }^{b}$ & $\begin{array}{l}\text { June- } \\
\text { Julyc }\end{array}$ \\
\hline Thalurania colombica & & $x$ & \\
\hline Damophila julie & $X$ & $x$ & $x$ \\
\hline Amazilia amazilia & $x$ & $x$ & $x$ \\
\hline Chalybura buffonii & $x$ & $x$ & $X$ \\
\hline Heliomaster longirostris & $X$ & $\mathrm{X}$ & $X$ \\
\hline Trogon melanurus & $x$ & $\mathrm{X}$ & $X$ \\
\hline Trogon violaceus & $x$ & $x$ & $x$ \\
\hline Ceryle torquata & & $x$ & \\
\hline Chloroceryle americana & & $x$ & $x$ \\
\hline Momotus momota & & $x$ & $\mathrm{x}$ \\
\hline Picumnus olivaceus & & $x$ & \\
\hline Picumnus sclateri & $x$ & $x$ & $x$ \\
\hline Piculus rubiginosus & & $x$ & $x$ \\
\hline Dryocopus lineatus & & $X$ & $x$ \\
\hline Veniliornis callonotus & & $\mathrm{x}$ & $\mathrm{X}$ \\
\hline Veniliornis kirkii & $X$ & $X$ & $x$ \\
\hline Campephilus guayaquilensis & $x$ & $\mathrm{X}$ & $\mathrm{X}$ \\
\hline Dendrocincla fuliginosa & $X$ & & $x$ \\
\hline Sittasomus griseicapillus & & $X$ & $x$ \\
\hline Xiphocolaptes promeropirhynchus & & $x$ & $X$ \\
\hline Lepidocolaptes souleyettit & & $x$ & $x$ \\
\hline Campylorhamphus trochilirostris & & $x$ & $x$ \\
\hline Furnarius leucopus & $x$ & $x$ & $x$ \\
\hline Synallaxis brachyura & $x$ & $x$ & $x$ \\
\hline Synallaxis tithys & $x$ & $x$ & $x$ \\
\hline Synallaxis azarae & $X$ & $x$ & $\mathrm{X}$ \\
\hline Hylocryptus erythrocephalus & $X$ & $x$ & $x$ \\
\hline Syndactyla ruficollis & & $\mathrm{X}$ & $x$ \\
\hline Xenops rutilans & & $X$ & $x$ \\
\hline Xenops minutus & & $x$ & \\
\hline Taraba major & & & $x$ \\
\hline Sakesphorus bernardi & & $x$ & $x$ \\
\hline Thamnophilus zarumae & $x$ & $\mathrm{X}$ & $x$ \\
\hline Dysithamnus mentalis & $x$ & $x$ & $x$ \\
\hline Pyriglena leuconota & $x$ & $\mathrm{X}$ & $x$ \\
\hline Myrmeciza griseiceps & $x$ & & $x$ \\
\hline Grallaria watkinsi & & $x$ & $x$ \\
\hline Grallaria guatimalensis & $x$ & & \\
\hline Melanopareia elegans & & & $x$ \\
\hline Zimmerius viridiflavus & & $\mathrm{X}$ & $\mathrm{X}$ \\
\hline Camptostoma obsoletum & $x$ & $x$ & $x$ \\
\hline Myiopagis subplacens & $x$ & $X$ & $x$ \\
\hline Mecocerculus calopterus & $\mathrm{x}$ & & $X$ \\
\hline Euscarthmus melorhyphus & & $\mathrm{X}$ & $x$ \\
\hline Mionectes oleagineus & & $X$ & $x$ \\
\hline Leptopogon superciliaris & $x$ & $?$ & \\
\hline Lophotriccus pileatus & $x$ & $x$ & $x$ \\
\hline Todirostrum cinereum & $x$ & $x$ & $x$ \\
\hline Tolmomyias sulphurescens & $x$ & $x$ & $x$ \\
\hline Platyrinchus mystaceus & & $X$ & \\
\hline Onychorhynchus coronatus & & $x$ & $x$ \\
\hline Myiobius atricaudus & & $X$ & $x$ \\
\hline Myiophobus fasciatus & & $x$ & $X$ \\
\hline
\end{tabular}


Appendix. (cont.)

\begin{tabular}{|c|c|c|c|}
\hline & $\begin{array}{l}\text { February- } \\
\text { March }^{2}\end{array}$ & July $^{\mathrm{b}}$ & $\begin{array}{l}\text { June- } \\
\text { Julyc }\end{array}$ \\
\hline Contopus fumigatus & & $x$ & $x$ \\
\hline Contopus cinereus & & $x$ & $x$ \\
\hline Lathrotriccus griseipectus & & $x$ & \\
\hline Pyrocephalus rubinus & & $x$ & $x$ \\
\hline Attila torridus & & $x$ & \\
\hline Myiarchus tuberculifer & & $x$ & $x$ \\
\hline Myiarchus phaeocephalus & $x$ & $x$ & $x$ \\
\hline Megarhynchus pitangua & & $x$ & $x$ \\
\hline Myiodynastes bairdii & & $x$ & $x$ \\
\hline Myiodynastes maculatus & & & $X$ \\
\hline Pachyramphus spodiurus & & $x$ & $x$ \\
\hline Pachyramphus albogriseus & & & $x$ \\
\hline Schiffornis turdinus & $x$ & $x$ & $x$ \\
\hline Manacus manacus & & $x$ & $x$ \\
\hline Progne chalybea & $x$ & $x$ & $x$ \\
\hline Cyanocorax mystacalis & & $x$ & \\
\hline Campylorhynchus fasciatus & $x$ & $x$ & $x$ \\
\hline Thryothorus sclateri & $x$ & $x$ & $x$ \\
\hline Troglodytes aedon & $x$ & $x$ & $x$ \\
\hline Henicorhina leucophrys & $x$ & $x$ & $x$ \\
\hline Mimus longicaudatus & & $x$ & $x$ \\
\hline Catharus dryas & $\mathrm{X}$ & & $x$ \\
\hline Catharus ustulatus & $x$ & & \\
\hline Turdus reevei & & $x$ & $x$ \\
\hline Turdus maculirostris & $x$ & $x$ & $x$ \\
\hline Ramphocaenus melanurus & $x$ & $x$ & $x$ \\
\hline Polioptila plumbea & $x$ & $x$ & $x$ \\
\hline Cyclarhis gujanensis & $x$ & $x$ & $x$ \\
\hline Vireo olivaceus & $x$ & & $x$ \\
\hline Hylophilus minor & $x$ & $x$ & $x$ \\
\hline Phrygilus plebejus & & $x$ & $x$ \\
\hline Sicalis flaveola & $x$ & $x$ & \\
\hline Poospiza hispaniolensis & & $\mathrm{x}$ & \\
\hline Rhodospingus cruentus & $x$ & $x$ & $x$ \\
\hline Volatinia jacarina & $x$ & $x$ & \\
\hline Sporophila americana & $x$ & $x$ & $x$ \\
\hline Sporophila nigricollis & $x$ & & $x$ \\
\hline Sporophila telasco & $x$ & & $x$ \\
\hline Tiaris obscura & & $x$ & $x$ \\
\hline Arremonops conirostris & & $x$ & \\
\hline Arremon aurantiirostris & & $x$ & $x$ \\
\hline Arremon abeillei & $x$ & $x$ & $x$ \\
\hline Atlapetes leucopterus & & $x$ & $x$ \\
\hline Atlapetes albiceps & & $x$ & $x$ \\
\hline Atlapetes torquatus & $x$ & $x$ & $x$ \\
\hline Pheucticus chrysopeplus & $x$ & $\mathrm{X}$ & $X$ \\
\hline Saltator maximus & $x$ & $x$ & $x$ \\
\hline Saltator albicollis & & $x$ & $x$ \\
\hline Cyanocompsa cyanoides & $x$ & $x$ & $x$ \\
\hline Conothraupis speculigera & $x$ & & \\
\hline Chlorospingus canigularis & $x$ & $x$ & $x$ \\
\hline Tachyphonus luctuosus & $x$ & & \\
\hline Piranga flaza & $x$ & $x$ & $x$ \\
\hline
\end{tabular}


Appendix. (cont.)

\begin{tabular}{|c|c|c|c|}
\hline & $\begin{array}{l}\text { February- } \\
\text { March }^{\mathrm{a}}\end{array}$ & July & $\begin{array}{l}\text { June- } \\
\text { July }\end{array}$ \\
\hline Thratipis episcopus & $x$ & $x$ & $\mathrm{x}$ \\
\hline Pipraeidea melanonota & $x$ & & \\
\hline Euphonia laniirostris & $x$ & $x$ & $x$ \\
\hline Euphonia xanthogaster & & $x$ & $x$ \\
\hline Tangara gyrola & $x$ & $\mathrm{x}$ & $x$ \\
\hline Coereba flaveola & $x$ & $x$ & $x$ \\
\hline Parula pitiayumi & $x$ & $x$ & $x$ \\
\hline Geothlypis aequinoctialis & $x$ & & $x$ \\
\hline Myioborus miniatus & & $x$ & $x$ \\
\hline Basileuterus trifasciatus & $x$ & $x$ & $x$ \\
\hline Basileuterus fraseri & $x$ & $x$ & $x$ \\
\hline Dives warszewiczi & & $x$ & \\
\hline Cacicus cela & & & $x$ \\
\hline Cacicus holosericeus & $x$ & $x$ & $x$ \\
\hline Icterus graceannae & & $x$ & $\mathrm{x}$ \\
\hline Icterus mesomelas & & $x$ & $x$ \\
\hline Carduelis siemiradzkii & ? & $x$ & $x$ \\
\hline
\end{tabular}

${ }^{a}$ M. Kessler (25 February-3 March 1986); data refer solely to the area around Campo Verde.

b T. A. Parker and W. Wust (23-27 July 1988).

"Wiedenfeld et al. (1985).

${ }^{d}$ Recognized as a species separate from Glaucidium brasilianum, following König (1991).

\section{References}

American Ornithologists' Union (1983) Check-list of North American birds. Sixth edition. Washington, D.C.: American Ornithologists' Union.

Belton, W. (1984) Birds of Rio Grande do Sul, Brazil. Part 1. Rheidae through Furnariidae. Bull. Amer. Mus. Nat. Hist. 178: 369-636.

Best, B. J. and Clarke, C. T. (1991) The threatened birds of the Sozoranga region, southwest Ecuador. Cambridge, U.K.: International Council for Bird Preservation (Study Report 44).

Best, B. J., ed. (1992) The threatened forests of south-west Ecuador. Leeds: Biosphere Publications.

Best, B. J., Clarke, C. T., Checker, M., Broom, A. L., Thewlis, R. M., Duckworth, W. and McNab, A. (1993a) Distributional records, natural history notes, and conservation of some poorly known birds from southwestern Ecuador and northwestern Peru. Bull. Brit. Orn. Club 113: 108-119.

Best, B. J., Clarke, C. T., Checker, M., Broom, A. L., Thewlis, R. M., Duckworth, W. and McNab, A. (1993b) Distributional records, natural history notes, and conservation of some poorly known birds from southwestern Ecuador and northwestern Peru. Bull. Brit. Orn. Club 113: 234-255.

Best, B. J. and Krabbe, N. (1994) A review of the status and conservation of the Rufousheaded Chachalaca. World Pheasant Assoc. J. 17-18: 45-56.

Best, B. J., Krabbe, N., Clarke, C. T. and Best, A. L. (1995) Red-masked Parakeet Aratinga erythrogenys and Grey-cheeked Parakeet Brotogeris pyrrhopterus: two threatened parrots from Tumbesian Ecuador and Peru? Bird Conserv. Internatn. 5: 233-250.

Blake, E. R. (1977) Manual of Neotropical birds, 1. Chicago: University of Chicago Press.

Chapman, F. M. (1917) The distribution of bird-life in Colombia: a contribution to a biological survey of South America. Bull. Amer. Mus. Nat. Hist. 36: 1-729. 
Chapman, F. M. (1919) Descriptions of proposed new birds from Peru, Bolivia, Brazil, and Colombia. Proc. Biol. Soc. Washington 32: 253-268.

Chapman, F. M. (1923) Descriptions of proposed new birds from Panama, Venezuela, Ecuador, Peru, and Bolivia. Amer. Mus. Novit. 67.

Chapman, F. M. (1926) The distribution of bird-life in Ecuador: a contribution to a study of the origin of Andean bird-life. Bull. Amer. Mus. Nat. Hist. 55: 1-784.

Collar, N. J., Gonzaga, L. P., Krabbe, N., Madroño Nieto, A., Naranjo, L. G., Parker, T. A., III and Wege, D. C. (1992) Threatened birds of the Americas: the ICBP/IUCN Red Data Book. Cambridge, U.K.: International Council for Bird Preservation.

Cory, C. B. and Hellmayr, C. E. (1924) Catalogue of birds of the Americas. Part III. Field Mus. Nat. Hist., Zool. Ser., 13.

Cracraft, J. (1985) Historical biogeography and patterns of differentiation within the South American avifauna: areas of endemism. Pp.49-84 in P. A. Buckley, M. S. Foster, E. S. Morton, R. S. Ridgely and F. G. Buckley, eds. Neotropical ornithology. Washington, D.C.: American Ornithologists' Union (Orn. Monogr. 36).

Dodson, C. H. and Gentry, A. H. (1991) Biological extinction in western Ecuador. Ann. Missouri Bot. Gard. 78: 273-295.

Dourojeanni, M. J. and Ponce, C. F. (1978) Los parques nacionales del Peru. Madrid: Instituto de la Caza Fotográfica y Ciencias de la Naturaleza.

Gentry, A. H. (1982) Phytogeographic patterns as evidence for a Chocó refuge. Pp.112136 in G. T. Prance, ed. Biological diversification in the tropics. New York: Columbia University Press.

Harris, R. (1985) Grey-cheeked Parakeets and other Brotogeris. Neptune City, New Jersey: TFH Publications, Inc.

Hellmayr, C. E. (1934) Catalogue of birds of the Americas. Part VII. Field Mus. Nat. Hist., Zool. Ser., 13.

Hellmayr, C. E. and Conover, B. (1942) Catalogue of birds of the Americas. Part I, no. 1. Field Mus. Nat. Hist., Zool. Ser., 13.

Hilty, S. L. and Brown, W. L. (1986) A guide to the birds of Colombia. Princeton: Princeton University Press.

Koepcke, H.-W. and Koepcke, M. (1966) Las aves silvestres de importancia económica del Perí, Part XIV. Lima: Ministerio de Agricultura.

König, C. (1991) Zur Taxonomie und Ökologie der Sperlingskäuze (Glaucidium spp.) des Andenraumes. Ökol. Vögel 13: 15-76.

Lanyon, W. E. and Lanyon, S. M. (1986) Generic status of Euler's Flycatcher: a morphological and biochemical study. Auk 103: 341-350.

McKitrick, M. C. and Zink, R. M. (1988) Species concepts in ornithology. Condor 90: 1-14.

Meyer de Schauensee, R. (1966) The species of birds of South America with their distribution. Narberth, Pennsylvania: Livingston Publishing Company.

Müller, P. (1973) The dispersal centres of terrestrial vertebrates in the Neotropical realm. The Hague: Junk.

Mulliken, T. and Thomsen, J. B. (1990). U. S. bird trade: the controversy continues although imports decline. Traffic USA 10: 1-11.

Parker, T. A., III, and Carr, J. L. (1992) Status of forest remnants in the Cordillera de la Costa and adjacent areas of southwestern Ecuador. Washington, D.C.: Conservation International (RAP Working Papers 2).

Parker, T. A., III, Fitzpatrick, J. W. and Stotz, D. F. (in press) Ecological and distributional databases. In D. F. Stotz, J. W. Fitzpatrick, T. A. Parker III and D. K. Moskovits. Neotropical birds: ecology and conservation. Chicago: University of Chicago Press.

Parker, T. A., III, Schulenberg, T. S., Graves, G. R. and Braun, M. J. (1985) The avifauna of the Huancabamba region, northern Peru. Pp.169-197 in P. A. Buckley, M. S. Foster, E. S. Morton, R. S. Ridgely and F. G. Buckley, eds. Neotropical ornithology. Washington, D.C.: American Ornithologists' Union (Orn. Monogr. 36). 
Paynter, R. A., Jr. (1960) Family Troglodytidae. Pp.379-440 in E. Mayr and J. C. Greenway, eds. Check-list of birds of the world, 9. Cambridge, Mass.: Museum of Comparative Zoology.

Paynter, R. A., Jr. (1972) Notes on the furnariid Automolus (Hylocryptus) erythrocephalus. Bull. Brit. Orn. Club 92: 154-155.

Paynter, R. A., Jr. (1993) Ornithological gazetteer of Ecuador. Second edition. Cambridge, Mass.: Museum of Comparative Zoology.

Peters, J. L. (1951) Check-list of birds of the world, 7. Cambridge, Mass.: Museum of Comparative Zoology.

Remsen, J. V., Jr. (1984) High incidence of "leapfrog" pattern of geographic variation in Andean birds: implications for the speciation process. Science 224: 171-173.

Remsen, J. V., Jr. and Parker, T. A., III (1984) Arboreal dead-leaf-searching birds of the neotropics. Condor 86: 36-41.

Ridgely, R. S. (1981) The current distribution and status of mainland neotropical parrots. Pp.233-384 in R. F. Pasquier, ed. Conservation of New World parrots. Washington, D.C.: Smithsonian Institution Press for the International Council for Bird Preservation (Techn. Publ, 1).

Ridgely, R. S. and Tudor, G. (1989) The birds of South America, 1. Austin, Texas: University of Texas Press.

Robbins, M. B. and Ridgely, R. S. (1990) The avifauna of an upper tropical cloud forest in southwestern Ecuador. Proc. Acad. Nat. Sci. Philadelphia 142: 59-71.

Schulenberg, T. S. and Parker, T. A., III (1981) Status and distribution of some northwest Peruvian birds. Condor 83: 209-216.

Tosi, J. A., Jr. (1960) Zonas de vida natural en el Perú: memoria explicativa sobre el mapa ecológico del Perí. Washington, D.C.: Instituto Interamericano de Ciencias Agrícolas de la OEA, Zona Andina, Proyecto 39, Programa de Cooperación Tecnica (Bol. Techn. 5).

Traylor, M. A., Jr. (1977) Tyrannidae. Pp.1-229 in M. A. Traylor, Jr., ed. Check-list of birds of the world, 8. Cambridge, Mass.: Museum of Comparative Zoology.

Wiedenfeld, D., Schulenberg, T. S. and Robbins, M. B. (1985) Birds of a tropical deciduous forest in extreme northwestern Peru. Pp.305-315 in P. A. Buckley, M. S. Foster, E. S. Morton, R. S. Ridgely and F. G. Buckley, eds. Neotropical ornithology. Washington, D.C.: American Ornithologists' Union (Orn. Monogr. 36).

Willis, E. O. (1981) Diversity in adversity: the behaviors of two subordinate antbirds. Arq. Zool. 30: 159-234.

Willis, E. O. and Oniki, Y. (1982) Behavior of Fringe-backed Fire-eyes (Pyriglena atra, Formicariidae): a test case for taxonomy versus conservation. Rev. Brasil. Biol. 42: 213223.

Zimmer, J. T. (1951) Studies of Peruvian birds. II. Amer. Mus Novit. 509.

\section{THEODORE A. PARKER III}

Conservation International, 1015 18th Street N.W., Suite 1000, Washington, D.C. 20036 , U.S.A., and Museum of Natural Science, 119 Foster Hall, Louisiana State University, Baton Rouge, LA 70808, U.S.A.

\section{THOMAS S. SCHULENBERG}

Committee on Evolutionary Biology, University of Chicago, Chicago, IL 60637, U.S.A, and Bird Division, Field Museum, Chicago, IL 60605, U.S.A.

Schiefer Weg 5, 37073 Göttingen, Germany. 


\section{WALTER H. WUST}

Huarol J-12, Los Manzanos, Lima 33, Peru.

Corresponding author: Thomas S. Schulenberg, Bird Division, Field Museum of Natural History, Roosevelt Road at Lake Shore Drive, Chicago IL 60605, U.S.A. 